\title{
A Large Chondroitin Sulfate Proteoglycan Has the Characteristics of a General Extracellular Matrix Component of Adult Brain
}

\author{
Mineo Iwata and Steven S. Carlson \\ Department of Physiology and Biophysics, University of Washington, Seattle, Washington 98195
}

Extracellular matrix (ECM) is a secreted extracellular network. Few components of adult brain ECM are known. We have identified a new, large chondroitin sulfate proteoglycan (T1 antigen) that acts like a general ECM protein of brain. First, it is present throughout the brain; second, it has the properties of an extracellular protein; and third, it is extracted only under denaturing conditions.

Immunocytochemical localization of the $\mathrm{T} 1$ antigen by light microscope shows it to be present throughout the rat brain in both white and gray matter. The $\mathrm{T} 1$ antigen outlines Purkinje and other large cells. No antigenicity is seen inside these cells.

Biochemical evidence suggests that the $\mathrm{T} 1$ antigen is extracellular rather than cytosolic or intravesicular. The T1 antigen is disulfide-linked to two other proteins. Disulfide bonds are found only in extracellular or intravesicular proteins, not in intracellular cytosolic proteins. Moreover, the T1 antigen is probably not intravesicular. Unlike intravesicular proteins, only a small amount of $\mathrm{T} 1$ antigen is solubilized by nondenaturing detergents.

While nondenaturing detergents extract but a small amount of $\mathrm{T} 1$ antigen from rat brain, the majority is solubilized by denaturing conditions ( $6 \mathrm{~m}$ guanidine- $\mathrm{HCl}$ ). This behavior is similar to that of ECM components in other tissues and is unlike that of membrane proteins, even those linked to the cytoskeleton. We hypothesize that the insolubility of the T1 antigen in brain is due to its presence in an extracellular aggregate.

The $\mathrm{T} 1$ antigen is a proteoglycan with a highly glycosylated protein core of $300 \mathrm{kDa}$. It does not appear to be related to the large, heavily glycosylated chondroitin sulfate proteoglycans aggrecan and versican, which were discovered in non-neural tissues. Antibodies to a 15 residue peptide present in both aggrecan and versican do not react with the $\mathrm{T} 1$ antigen.

[Key words: brain extracellular matrix, extracellular matrix, chondroitin sulfate proteoglycan, aggrecan antibodies, cerebellum, hippocampus]

\footnotetext{
Received May 20, 1992; accepted July 16, 1992.

We are grateful to Rebecca Cruz for technical assistance and Lorraine Gibbs for initial help with immunocytochemical methods. We thank V. Hascall and J. D. Sandy for the sample of cow nasal cartilage proteoglycans (AlDI), and $\mathrm{T}$. Wight and E. Schonherr for media from cultured monkey smooth muscle cells. We also thank Tom Wight, Bertil Hille, Todd Scranton, Anna Davis, and Bill Sunderland for useful discussions. For editorial help, we thank C. Missimer and L. Levy. This research was supported by a grant from the National Institutes of Health (NS22367) to S.S.C.

Correspondence should be addressed to Steven S. Carlson at the above address. Copyright (c) 1993 Society for Neuroscience $0270-6474 / 93 / 130195-13 \$ 05.00 / 0$
}

Until recently it appeared that the adult brain had no organized extracellular matrix (ECM) (Sanes, 1989). It seemed that few hallmarks of ECM were present in the brain. Basement membranes, morphologically distinct structures of the ECM, are not present in the brain other than on the meningeal surfaces and blood vessels. The well-characterized forms of collagen are important structural components of many ECMs. They are not present between neurons and/or glial cells. The ECM molecule fibronectin appears transiently during development, but is not present in adult brain outside of the few basement membranes that exist in the CNS. Although proteoglycans exist in adult brain (Aquino et al., 1984; Klinger et al., 1985; Hoffman et al., 1988; Oohira et al., 1988; Herndon and Lander, 1990; Rauch et al., 1991), many can be extracted by homogenization of the tissue in physiological salt or nondenaturing detergent solutions. However, tissues with a well-studied ECM require denaturing conditions for the extraction of proteoglycans. Few ECM proteins that require denaturing conditions for extraction have been studied in the brain.

Only a few ECM components have been identified in adult brain. Tenascin/cytotactin is detectable in adult brain (Crossin et al., 1986; Hoffman et al., 1988). Merosin, an isoform of laminin, is present in adult brain with restricted distribution (Portera-Cailliau et al., 1990). A chondroitin sulfate proteoglycan, Cat-301, which is associated with the surface of a subset of neurons, has been identified and characterized (Zaremba et al., 1989). A protein showing sequence homology to SPARC is expressed in adult brain (Johnston et al., 1990). Hyaluronic acid is present in the adult brain (Margolis et al., 1975) but is reported to be intracellular (Ripellino et al., 1988).

Despite meager evidence to date for ECM in the adult brain, one would presume that it exists there as it does in other tissues, which contain large, space-filling proteoglycans, collagens, and fibronectin. As in other tissues, these molecules would organize the extracellular space in the CNS. The scant information about adult brain ECM components is an unfortunate state of affairs, given growing interest in the determinants of brain extracellular space (Abbott, 1986; McBain et al., 1990), the pathology of amyloidoses in the brain (Snow and Wight, 1989), and the possibility of synaptic rearrangement in the adult nervous system (Purves et al., 1986, 1987). One might expect adult brain ECM to play an important role in all these processes.

Here we report the identification and characterization of a large, heavily glycosylated chondroitin sulfate proteoglycan, which we hypothesize to be a new general component of adult brain ECM. Our hypothesis is based on the following reasons: (1) Immunocytochemically, this proteoglycan is present throughout the brain and is seen surrounding large cells. No proteoglycan is seen within these cells. (2) Disulfide linkages in 
this proteoglycan combined with the inability of nondenaturing detergents to extract the $\mathrm{T} 1$ antigen suggest that this proteoglycan is extracellular, rather than cytosolic or intravesicular. (3) This proteoglycan is solubilized from brain tissue only by denaturing conditions, a behavior similar to ECM proteins in other tissues. This behavior suggests that the proteoglycan is associated in an extracellular network. (4) This proteoglycan is distinct from the well-known heavily glycosylated chondroitin sulfatc proteoglycans aggrecan and versican, which are present in nonneural tissues.

\section{Materials and Methods}

Materials. Molecular weight standard markers for gel electrophoresis were purchased from Bio-Rad (Richmond, CA). ${ }^{125}$ I-sheep anti-mouse IgG (heavy and light chain specific), ${ }^{125} \mathrm{I}$-protein $\mathrm{G}, \mathrm{Na}^{125} \mathrm{I}$, Enhanced chemiluminescence (ECL) assay kit, and rainbow molecular weight standard markers were purchased from Amersham (Arlington Heights, IL). Purified laminin was purchased from UBI (New York, NY). Goat antimouse IgG and Triton X-100 were from Boehringer Mannheim Biochemicals (Indianapolis, IN); nitrocellulose (BA85), from Schleicher \& Schuell (Keene, NH); and DEAE Sephacel, from Pharmacia (Piscataway, NJ). X-ray film (X-Omat AR) is from Kodak (Rochester, NY); iodogen, from Pierce Chemical (Rockford, IL); and ultrapure urea, from ICN Biochemicals (Costa Mesa, CA). Glycosaminoglycan lyases were from Seikagaku America (Rockville, MD). Immunobeads (goat anti-mouse immunoglobulin; $\mu$-chain and $\gamma$-chain specific), phosphatidyl choline, octyl-Sepharose, epoxy-activated Sepharose, protease-free bovine serum albumin, and all common chemicals were from Sigma Chemical (St. Louis, MO). Monoclonal culture supernatants containing the anti$\mathrm{T} 1$, anti-SV1, anti-SV2, or anti-SV4 monoclonal antibody $(\mathrm{mAb})$ were prepared by standard procedures (Hockfield et al., in press). The epitopes identified by the anti-SV1, anti-SV2, and anti-SV4 $\mathrm{mAb}$ are described in Carlson (1989).

Immunocytochemical reagents were purchased from the following companies: biotinylated goat anti-mouse $\mathrm{IgG}$ (heavy and light chain specific) from Jackson Immunoresearch Labs (West Grove, PA), Vectastain $\mathrm{ABC}$ kit from Vector Laboratories (Burlingame, CA), purified mouse IgM (MOPC 104E) from Sigma Chemical Co. (St. Louis, MO).

The Sprague-Dawley rats at the age of 10 weeks were obtained from Tyler Labs (Bellevue, WA). Synaptic vesicles were purified from electric organ by the methods of Carlson et al. (1978) and were a gift from Todd Scranton (University of Washington).

The A1D1 proteoglycan fraction from calf nasal cartilage was a gift from Dr. Hascall (National Institutes of Health) and Dr. J. D. Sandy (Shriner's Hospital) as a source of aggrecan. Monkey smooth muscle cell culture media were provided by Dr. T. Wight and Dr. E. Schonherr (University of Washington). The proteoglycans contained in this media were partially purified by chromatography on DEAE Sephacel according to their procedures (Schonherr et al., 1991).

Immunocytochemistry. Rat brain tissue was cut into four sagittal tissue slabs; immersion fixed in $4 \%$ paraformaldehyde in $0.1 \mathrm{M}$ Na phosphate, $\mathrm{pH} 7.4$, overnight at $4^{\circ} \mathrm{C}$; and embedded in paraffin. Ten micrometer sagittal sections were cut, mounted on microscope slides, deparaffinized, and rehydrated. The slides were incubated for $1 \mathrm{hr}$ with $5 \%$ goat serum in PBS (to prevent nonspecific staining of the sections by antibodies), overnight with $\mathrm{mAb}$ (monoclonal supernatant diluted $1: 5$ with $5 \%$ horse serum in PBS), 15 min with $0.75 \%$ hydrogen peroxide to inactivate endogenous peroxidases, and $1.5 \mathrm{hr}$ with biotinylated secondary antibody $(5 \mu \mathrm{g} / \mathrm{ml}$ in $5 \%$ horse serum in PBS). The sections were incubated with streptavidin-biotin HRP complex using the Vectastain $A B C$ kit of Vector Laboratories (Burlingame, $C A$ ) according to the manufacturer's instructions. A solution of $0.3 \%$ hydrogen peroxide, 100

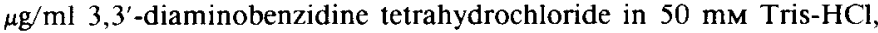
$\mathrm{pH} 7.6$, was used as a substrate for the immunolocalized peroxidase, resulting in a brown reaction product.

In addition to the method described above, we tried several other fixation and embedding methods of rat brain to detect the $T 1$ antigen immunocytochemically. These methods included the immersion fixation in methyl Carnoy's fixative and embedding the tissue in paraffin Also, rat brain was perfused with $4 \%$ paraformaldehyde, $0.1 \mathrm{M} \mathrm{Na}$ phosphate, $\mathrm{pH} 7.4$, or/and immersed in this same fixative for $18 \mathrm{hr}$ at $4^{\circ} \mathrm{C}$, cryoprotected with $20 \%$ sucrose, and quick frozen for sectioning in the cryostat. Ten micrometer sagittal sections of brain tissue were prepared by these methods and stained as described above; all these sections showed similar immunoreactivity. However, both the preservation of structure and antigenic signal were best in tissue fixed with

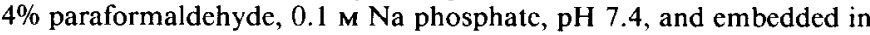
paraffin as described above.

Preparation of brain extracts. Rat brains were sequentially extracted by the following procedure: $1 \mathrm{gm}$ of brain tissue was suspended in 5 vol of $0.15 \mathrm{M} \mathrm{NaCl}, 10 \mathrm{~mm}$ EDTA, $20 \mathrm{~mm}$ HEPES, $\mathrm{pH} 7.4$, and $5 \mathrm{ml} /$ liter of protease inhibitor cocktail $(0.1 \mathrm{gm} / \mathrm{ml}$ of iodoacetamide, $6.3 \mu \mathrm{l} /$ $\mathrm{ml}$ of diisopropylfluorophosphate, $2 \mathrm{mg} / \mathrm{ml}$ of pepstatin, chymostatin, and leupeptin in dimethyl sulfoxide), and homogenized with a glass homogenizer with Teflon plunger in ice. The homogenate was passed through cheesecloth and centrifuged at $140,000 \times g$ for $2 \mathrm{hr}$ at $4^{\circ} \mathrm{C}$ using a Beckman L8-M ultracentrifuge with a 50.2 Ti rotor (Beckman, Palo Alto, CA). The supernatant was saved and the pellet was reextracted under the same conditions as the first homogenization with $1 \%$ Triton $\mathrm{X}-100,0.15 \mathrm{~m} \mathrm{NaCl}, 10 \mathrm{~mm}$ EDTA, $20 \mathrm{~mm}$ HEPES, $\mathrm{pH} 7.4$, and $5 \mathrm{ml} /$ liter of protease inhibitory cocktail. In some cxpcriments $2 \%$ CHAPS, (3-[(3-cholamidopropyl)-dimethylammonio]-1-propanesulfonate), $9 \mathrm{~mm}$ deoxycholate, or $60 \mathrm{~mm}$ octyl glucoside was substituted for $1 \%$ Triton $X-100$. Additionally, $0.5 \mathrm{M} \mathrm{NaCl}$ was substituted for $0.15 \mathrm{M} \mathrm{NaCl}$ in the $1 \%$ Triton $X-100$ solution. The resulting second supernatant was also saved, and the pellet was homogenized under the same conditions with $6 \mathrm{~m}$ guanidine- $\mathrm{HCl}, 2 \%$ CHAPS, $10 \mathrm{~mm}$ EDTA, $50 \mathrm{~mm}$ HEPES $\mathrm{pH} 7.4$, and $5 \mathrm{ml} /$ liter of protease inhibitor cocktail. The homogenate was vigorously stirred for $1 \mathrm{hr}$ at $4^{\circ} \mathrm{C}$ and centrifuged as described above, and the resulting supernatant was decanted and saved. The first supernatant is referred to as the "salt extract," the second as the "Triton extract," and the third as the "guanidine extract."

Under the above sedimentation conditions, the smallest particle to be completely removed from the supernatant should have a sedimentation coefficient of $74 \mathrm{~S}$. This sedimentation cocfficient is calculated using a $k$ factor of 148.8 at $140,000 \times g$ for the $50.2 \mathrm{Ti}$ rotor. The coefficient is applicable to the density and viscosity of our extracting solutions at $4^{\circ} \mathrm{C}$. We would expect the $S_{20, \mu^{\circ}}$ for such a particle to be larger due to solvent viscosity and density effects.

$\mathrm{CsCl}$ equilibrium density gradient and DEAE Sephacel chromatography of the brain extracts. The salt extract, Triton extract, and guanidine extract were brought to $4 \mathrm{~m}$ guanidine- $\mathrm{HCl}, 1.5-2 \% \mathrm{CHAPS}, 10 \mathrm{~mm}$ EDTA, 10 mm HEPES, pH 7.4, by addition of solid guanidine- $\mathrm{HCl}$, CHAPS, and/or dilution with the appropriate solution. The final volume of each extract/gm brain was adjusted to be the same; $5 \mu \mathrm{l}$ of protease inhibitor cocktail were added per milliliter of extract, and then $0.55 \mathrm{gm}$ of solid $\mathrm{CsCl}$ was added per gram of extract solution. The extracts were centrifuged at $28,000 \times \mathrm{g}$ for $30 \mathrm{~min}$ at $4^{\circ} \mathrm{C}$. The supernatants were carefully collected and recentrifuged at $160,000 \times g$ for $20 \mathrm{hr}$ at $10^{\circ} \mathrm{C}$ using Beckman L8-M ultracentrifuge with vertical rotor (Beckman, VTi50). Fourteen to fifteen fractions were collected from the bottom of the tube and the Tl antigenicity was monitored by dot immunoassay.

The peak fractions of $\mathrm{T} 1$ antigenicity (three or four fractions from the bottom of gradient) were pooled. Proteoglycans were concentrated by ethanol precipitation (Iwata and (arlson, 1991) and solubilized in $8 \mathrm{~m}$ urea, $0.11 \mathrm{~m} \mathrm{NaCl}, 50 \mathrm{~mm}$ sodium acetate, $\mathrm{pH} 4.9,0.2 \%$ CHAPS, $2 \mathrm{mM}$ EDTA, and $5 \mu \mathrm{l} / \mathrm{ml}$ protease inhibitor cocktail. After centrifuging at $28,000 \times g$ for $20 \mathrm{~min}$, the resulting supernatant was applied to a column of DEAE Sephacel as described by Carlson and Wight (1987). Bound materials were eluted with a linear $\mathrm{NaCl}$ gradient of $0.11 \mathrm{M}$ to $1.4 \mathrm{~m}$ in $8 \mathrm{~m}$ urea, $50 \mathrm{~mm}$ sodium acetate, $\mathrm{pH} \mathrm{4.9,0.2 \%} \mathrm{CHAPS,} 2 \mathrm{~mm}$ EDTA. The eluting antigenicity was monitored with the dot immunoassay.

Liposome intercalation of proteins. Proteins were incorporated into liposome bilayer by the method of Carlson et al. (1986). Briefly, liposomes were formed by dissolving phosphatidylcholine in the buffer $(8$ $\mathrm{M}$ urea, $2 \%$ cholate, $0.1 \mathrm{M} \mathrm{NaCl}, 20 \mathrm{~mm}$ HEPES, pH 7.4, and $0.02 \%$ azide) containing either the $\mathrm{T} 1$ antigen (partially purified by chromatography on DEAE Sephacel) of purified synaptic vesicles $(0.14 \mu \mathrm{g}$ protein in $0.25 \mathrm{ml}$ ) that contained the SVI proteoglycan. The detergent was then removed by dialyzing against $0.1 \mathrm{M} \mathrm{NaCl}, 20 \mathrm{~mm}$ HEPES, $\mathrm{pH}$ 7.4 , and $0.02 \%$ azide at $22^{\circ} \mathrm{C}$ for $25 \mathrm{hr}$. The dialyzed samples were made $45 \%$ sucrose by adding solid sucrose and layered under a $5-35 \%$ of linear sucrose gradient. These gradients were centrifuged at $35,000 \mathrm{rpm}$ $\left(160,000 \times g\right.$ average) for $20 \mathrm{hr}$ at $10^{\circ} \mathrm{C}$ with Beckman SW41Ti rotor. Fractions were collected, and the Tl and SVI antigenicities were determined by dot immunoassay as described below.

Dot immunoassay. $\mathrm{T} 1$ and SV 1 antigenicities were monitored by dot immunoassay according to the methods of Iwata and Carlson (1991) 
with a secondary probe of either ${ }^{125}$ I-labeled anti-mouse IgG antibody (heavy and light chain specific), or a mixture of goat anti-mouse IgG (heavy and light chain specific) in combination with ${ }^{125}$ I-protein G. Even though the $\mathrm{T} 1 \mathrm{mAb}$ is an IgM, these probes bind to the light chain. The ${ }^{125} \mathrm{I}$-protein $\mathrm{G}$ /anti-mouse IgG probe was used for detecting $\mathrm{Tl}$ antigenicity when rat brain extracts were chromatographed on DEAE Sephacel. The dot blot assay was about 10 times morc sensitive with the ${ }^{125} \mathrm{I}$-protein $\mathrm{G} /$ anti-mouse IgG probe than with the ${ }^{125} \mathrm{I}$-anti-mouse IgG.

$S D S-P A G E$ and immunoblotting. SDS polyacrylamide gels were formed with a linear gradient of $2.4-14 \%$ acrylamide (Iwata and Carlson, 1991). Immunoblots of these gels were probed sequentially with primary antibodies (various mouse monoclonal antibodies or rabbit $a-H A L$ antibody), then HRP-labeled secondary antibodies against the specific primary antibody. We followed previously described procedures (Carlson and Kelly, 1983, 1987; Iwata and Carlson, 1991). Bound HRP activity was detected by enzyme chemiluminescent method using Amersham's ECL kit following the instructions provided by the manufacturer (Amersham, Arlington Heights, IL). Autoradiography for ${ }^{125}$ I-labeled samples subjected to SDS-PAGE was done by exposing the polyacrylamide gels to $\mathrm{X}$-ray film with an intensifying screen (DuPont).

The molecular weight estimates from SDS-PAGE were made using the following molecular weight standards: laminin A chain $(400 \mathrm{kDa})$, laminin B chain $(220 \mathrm{kDa})$, myosin $(200 \mathrm{kDa})$, phosphorylase b $(92.5$ kDa), BSA (69 kDa), ovalbumin (46 kDa), carbonic anhydrase (30 kDa), trypsin inhibitor (21.5 kDa), lysozyme (14.5). The average $M_{r}$ and standard deviations were calculated using four or five separate SDS-polyacrylamide gels.

Iodination of brain $\mathrm{Tl}$ antigen and immunoprecipitation. The $\mathrm{CsCl}$ density gradient fractions with the highest concentration of $\mathrm{T} 1$ antigen were pooled. We labeled the proteins contained in these pooled fractions with $\mathrm{Na}^{125} \mathrm{I}$ using iodogen as described previously (Carlson et al., 1986). The iodinated proteoglycans were applied to a small column $(0.1 \mathrm{ml})$ of DEAE Sephacel equilibrated with $0.11 \mathrm{~m} \mathrm{NaCl}, 8 \mathrm{~m}$ urea, $50 \mathrm{~mm}$ sodium acetate, $\mathrm{pH} 4.9,0.2 \%$ CHAPS, 2 mM EDTA. The bound proteins were eluted with a linear $\mathrm{NaCl}$ gradient of $0.11-1.4 \mathrm{M}$ in the same urea solution. The ${ }^{125}$ I-labeled $\mathrm{T} 1$ antigen that eluted from the column was immunoprecipitated by the anti-T1 mAb with immunobeads as described elsewhere (Iwata and Carlson, 1991). Anti-T1 mAb can immunoprecipitate more than $60 \%$ of the iodinated antigen, whereas control beads coupled with mAbs to irrelevant antigens, MOPC 104E, anti-SV2 (Buckley and Kelly, 1985), and anti-SV4 (Iwata and Carlson, 1991 ), give less than $4 \%$.

Glycosaminoglycan lyase digestions. ${ }^{125} \mathrm{I}$-brain $\mathrm{T} 1$ antigen was collected from fractions of DEAE Sephacel chromatography, boiled for 3 min in the presence of $1 \%$ SDS and $1 \%$ 2-mercaptoethanol, diluted $200 \times$ with the immunoprecipitation buffer $(0.15 \mathrm{M} \mathrm{NaCl}, 10 \mathrm{~mm}$ Tris, pH $7.5,0.05 \%$ Nonidet P40, $0.02 \%$ sodium azide, $1 \mathrm{mg} / \mathrm{ml}$ of BSA), and immunoprecipitated by anti-T1 or control antibodies with immunobeads. The immunobeads $(10-20 \mu \mathrm{l}$ of a $10 \mathrm{mg} / \mathrm{ml}$ suspension) that had bound the ${ }^{125} \mathrm{I}$-brain T 1 antigen $\left(1-5 \times 10^{3} \mathrm{cpm}\right)$ were washed three times with the immunoprecipitation buffer $(1 \mathrm{ml})$ and once with $\mathrm{H}, \mathrm{O}(1 \mathrm{ml})$. The bead pellet was suspended in $50 \mu \mathrm{l}$ of $30 \mathrm{~mm}$ sodium acetate, $10 \mathrm{~mm}$ EDTA, $0.02 \%$ CHAPS, $100 \mathrm{~mm}$ Tris- $\mathrm{HCl}, \mathrm{pH} 8.0,1.2$ $\mathrm{mg} / \mathrm{ml}$ of protease-free BSA, $0.02 \mathrm{mg} / \mathrm{ml}$ iodoacetamide, $0.5 \mathrm{~mm}$ phenylmethylsulfonyl fluoride, and $2 \mu \mathrm{g} / \mathrm{ml}$ of chymostatin, leupeptin, and pepstatin. These immunobeads with the bound ${ }^{125} \mathrm{I}-\mathrm{T} 1$ antigen were subjected to glycosaminoglycan lyase digestion for $2 \mathrm{hr}$ at room temperature by addition of protease-free chondroitinase $A B C(0.1 \mathrm{U})$, keratinases I $(0.1 \mathrm{U})$ and II $(0.01 \mathrm{U})$, or heparitinase $(0.01 \mathrm{U})$. These conditions for glycosaminoglycan lyase digestions are recommended by Oike et al. (1980), with minor modifications. The digestion was stopped by boiling for $3 \mathrm{~min}$ in the presence of $1 \% \mathrm{SDS}$ and $1 \% 2$-mercaptoethanol. The digested T1 antigen was analyzed by SDS-PAGE and autoradiography. We eliminated the possibility of any contaminating proteases by using protease-free reagents (chondroitinase $\mathrm{ABC}$ and $\mathrm{BSA}$ ) and by adding protease inhibitors (see above) during the glycosaminoglycan lyase digestion. No protease digestion of BSA was observed during the lyase digestions. To ensure that all of the glycosaminoglycan lyases were active, parallel reactions containing the appropriate glycosaminoglycan were performed and analyzed by cellulose acetate electrophoresis (Carlson and Wight, 1987).

The relative amounts of the $T 1$ core proteins after chondroitin $A B C$ lyase digestion were determined from densitometry of the SDS-PAGE autoradiograms, similar to those used in Figure 6. (The optical densities used in the determination were in the linear range of optical density vs exposure time.) The optical densities resulting from densitometry were normalized by the calculated molecular weights for each protein core. The $450 \mathrm{kDa}$ and $220 \mathrm{kDa}$ core proteins represent $5 \% \pm 1(\mathrm{SD})$ and $3 \% \pm 1$ (SD) of the $300 \mathrm{kDa}$ protein, respectively. To calculate these percentages, we had to assume that the number of iodinated sites/unit of molecular weight was the same for each core protein. To test this assumption, we determined the number of tyrosine residues/amino acid residue for the following sequenced proteoglycans: aggrecan (Doege et al., 1987), versican (Zimmermann and Ruoslahti, 1989), NG2 (Nishiyama ct al., 1991), and biglycan (Fisher et al., 1989). The range of values differed by a factor of 2 . Thus, the $450 \mathrm{kDa}$ and $220 \mathrm{kDa}$ proteins could represent $3-7 \%$ and $2-4 \%$ of the $300 \mathrm{kDa}$ protein, respectively.

Synthetic peptide and the production of anti-peptide antibody. A 15 amino acid peptide, CDAGWLADQTVRYPI, which corresponds to residues 199-213 of aggrecan (Doege et al., 1987), was synthesized by the Peptide Synthesis Facility of the Howard Hughes Institute at the University of Washington using an automated peptide synthesizer. This 15 amino acid sequence is part of the G1 hyaluronic acid binding region of aggrecan (Doege et al., 1987). The purity of the peptide was confirmed by HPLC with C 18 reverse-phase column. Ten milligrams of the peptide were coupled to $30 \mathrm{mg}$ of keyhole limpet hemocyanin (KLH; Calbiochem) with sulfosuccinimidyl 4-( $N$-maleimidomethyl)cyclohexane-1carboxylate (Pierce) as described by Marcantonio and Hynes (1988). Antibodies against the peptide were produced by immunizing rabbits subcutaneously with $5 \mathrm{mg}$ of the peptide coupled to the hemocyanin mixed with Freund's complete adjuvant. Immunization was repeated with 2 week intervals in the same method except incomplete adjuvant was used.

Titer of the antiserum was measured by microtiter well assay. The peptide ( $1 \mu \mathrm{g} /$ well) was incubated overnight in 96-well plate (Costar) coated with nitrocellulose (Iwata and Carlson, 1991). The wells were washed three times with TBS $(0.15 \mathrm{NaCl}, 10 \mathrm{~mm}$ Tris, pH 7.5) and blocked with 5\% RSA in TBS. The serially diluted serum was added to the plate and incubated overnight at $22^{\circ} \mathrm{C}$. After four washes with TBS containing $0.05 \%$ Triton $X-100$, iodinated anti-rabbit antibody (Amersham) was added at 1:400 dilution and incubated for $1 \mathrm{hr}$. The plate was washed as in the previous step and bound radioactivity was measured by a gamma counter.

The specific antibodies against the peptide (a-HAL) were affinity purified. The peptide was coupled to epoxy-activated Sepharose according to the manufacturer's protocol at a concentration of $1 \mathrm{mg}$ peptide $/ \mathrm{ml}$ beads. KLH was also coupled to epoxy-activated Sepharose in order to remove the antibodies against the carrier. The immune serum was diluted three times with TBS and applied to KLH-affinity column. Molecules in the pass-through fractions were then applied to the peptide affinity column three times. After washing with TBS, the bound molecules were eluted with $50 \mathrm{~mm}$ CAPS (3-[cyclohexylamino]-1-propanesulfonic acid), $\mathrm{pH} 11.5$, and the fractions were immediately neutralized with $1 \mathrm{M}$ Tris- $\mathrm{HCl}, \mathrm{pH}$ 7.5. The protein concentration of fractions was measured at absorbance of $280 \mathrm{~nm}$ and the titer was determined as described above. The peak fractions of the antibody were pooled and dialyzed against TBS.

Affinity purified anti-peptide antibodies (a-HAL) were used for all Western blots described here. To inhibit the a-HAL antibody from binding to peptide or protein antigen, $1 \mu \mathrm{g}$ of the purified antibody was incubated with $4.4 \mathrm{mg}$ of the peptide for $30 \mathrm{~min}$ at $22^{\circ} \mathrm{C}$ and then added to Western blots or 96 -well plates.

\section{Results}

\section{The TI epitope}

Previously we identified, purified, and characterized a large $\left(10^{\circ}\right.$ Da) basement membrane-associated chondroitin sulfate/keratan sulfate proteoglycan, PG-1000, from elasmobranch electric organ (Carlson et al., 1986; Carlson and Wight, 1987; Iwata and Carlson, 1991). We generated an $\mathrm{mAb}$, anti-T 1, which identifies PG-1000 in electric organ (Iwata and Carlson, 1991). The epitope $(\mathrm{T} 1)$ that this $\mathrm{mAb}$ identifies is destroyed by pronase digestion of PG-1000 (Iwata and Carlson, 1991) and is removed from PG-1000 by chondroitin ABC lyase digestion (M. Iwata and S. S. Carlson, unpublished observations). As we show here, the $\mathrm{T} 1$ epitope is also removed by chondroitin $\mathrm{ABC}$ lyase digestion of a chondroitin sulfate proteoglycan from rat brain. The $\mathrm{T} 1$ epitope is not present in commercial preparations of chon- 

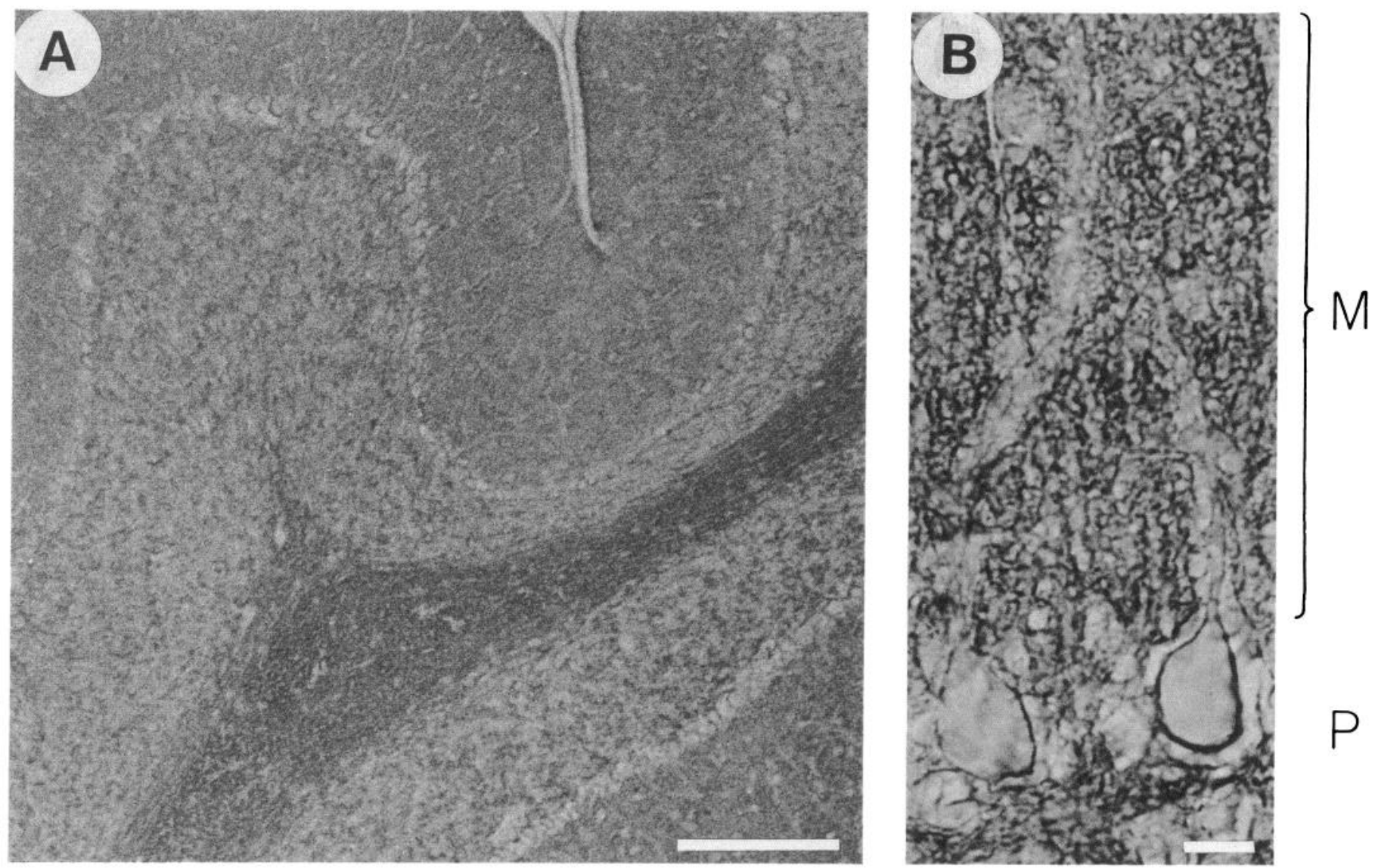

Figure 1. Localization of $\mathrm{T} 1$ antigenicity in the rat cerebellum. A sagittal section of rat cerebellum stained with the anti-T1 mAb $(A)$ and a higher magnification of the same section $(B)$ showing part of the molecular layer $(M)$ and the Purkinje cell layer $(P)$. The bound mAb was visualized with biotinylated goat anti-mouse IgG (heavy and light chain specific), streptavidin, and biotinylated HRP. T1 antigenicity is present throughout in both gray and white matter. The staining is evident surrounding Purkinje cells in $B$. Scale bars: $A, 200 \mu \mathrm{m} ; B, 13.3 \mu \mathrm{m}$.

droitin sulfate (Iwata and Carlson, 1991). The exact nature of the $\mathrm{T} 1$ antigenic site is not known, but perhaps it consists of polypeptide and glycosaminoglycan chains. In the experiments described in this article, the T1 site is used as a marker to identify a unique proteoglycan in the brain.

\section{$T 1$ antigenicity is present throughout the rat brain in both gray and white matter}

Immunocytochemistry demonstrates the presence of T1 antigenicity throughout the rat brain. When sagittal sections of the cerebellum are exposed to the anti- $\mathrm{T} 1 \mathrm{mAb}$, the molecular layer, Purkinje cell layer, granule cell layer, and white matter all stain with the $\mathrm{mAb}$ (Fig. 1A). The staining of white matter is slightly stronger than that in the gray matter. T1 antigenicity appears extracellular because the T1 antigenicity surrounds the Purkinje cells and none is present inside these cells (Fig. 1B). A control monoclonal antibody shows no staining (data not shown).

Although T1 antigenicity is present throughout the brain, it is not uniform. More antigenicity is seen in fiber tracts of the cerebellum (see Fig. $1 A$ ). In another example, the hilar region of the dentate gyrus shows more $\mathrm{T} 1$ antigenicity (Fig. $2 A$ ) than other regions of the dentate. This antigenicity surrounds large cells in the hilar region. Using adjacent brain sections, we detected no antigenicity with a control $\mathrm{mAb}$ (MOPC) in the same region of the dentate gyrus (Fig. $2 B$ ).

\section{Extraction of rat brain $T 1$ antigenicity requires denaturing conditions}

In order to determine the optimum extraction conditions for T1 antigen in brain tissue, three consecutive extractions were performed: first with a solution containing physiological salt, then a nondenaturing detergent, and finally with a chaotropic agent. The resulting extracts were subjected to sedimentation equilibrium on $\mathrm{CsCl}$ density gradients to separate the $\mathrm{T} 1$ antigen from the bulk of the extracted protein. Brain tissue was extracted by these steps: (1) $0.15 \mathrm{M} \mathrm{NaCl}$ solution containing EDTA, (2) the same solution containing $1 \%$ Triton X-100, and (3) a $6 \mathrm{M}$ guanidine- $\mathrm{HCl}$ and $2 \% \mathrm{CHAPS}$ solution. The tissue was homogenized in the first solution, and then the insoluble material was pelleted by centrifugation. The pellet was rehomogenized in the Triton X-100 solution, with the insoluble material again removed by centrifugation. This detergent-insoluble pellet was then extracted twice with the guanidine- $\mathrm{HCl}$ solution, the insoluble material being removed by centrifugation. Guanidine$\mathrm{HCl}$ was made $4 \mathrm{M}$ in each supernatant, solid $\mathrm{CsCl}$ was added $(0.55 \mathrm{gm} / \mathrm{gm}$ supernatant $)$, and the supernatants were subjected to sedimentation equilibrium centrifugation.

Brain $\mathrm{T} 1$ antigen is found in the high-density region of the $\mathrm{CsCl}$ density gradients (Fig. 3, fractions 1 and 2). The majority of rat brain $\mathrm{T} 1$ antigen requires denaturing conditions to be 


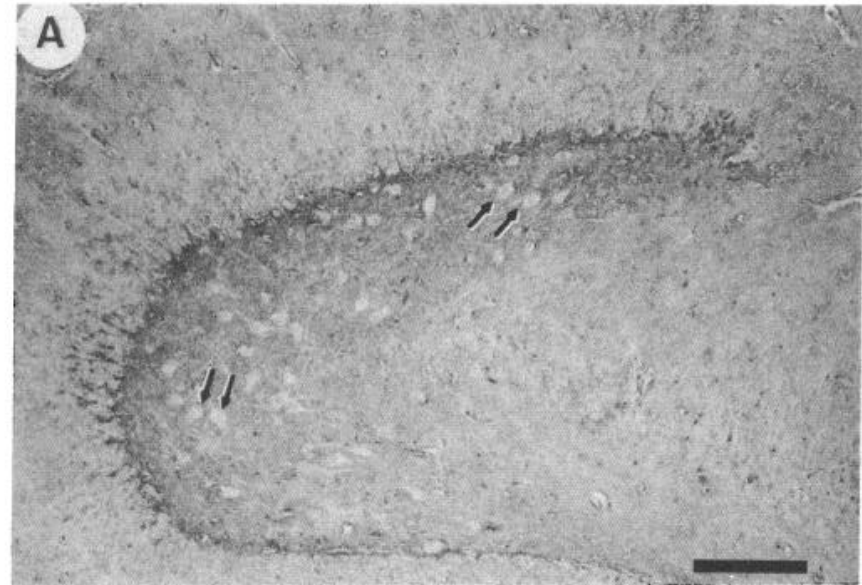

B

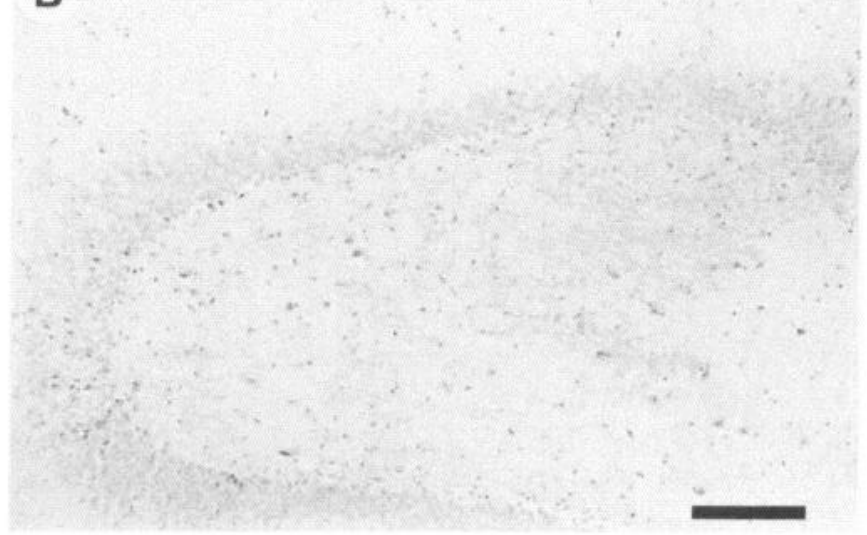

Figure 2. T1 antigenicity localized in a region of the hippocampus of the rat brain. Sagittal sections of rat brain exposing the hilar region of the dentate gyrus were stained with anti-T1 $\mathrm{mAb}(A)$ or a control (MOPC $104 \mathrm{E}) \mathrm{mAb}(B)$. The bound $\mathrm{mAb}$ was visualized with biotinylated goat anti-mouse IgG (heavy and light chain specific), streptavidin, and biotinylated HRP. The sections were counterstained with cresyl violet, which highlights the cell nuclei. Although staining by the anti-T1 mAb is found everywhere in the section, a strong zone of staining is present inside the granule cell layer. In this area, the antigenic staining is seen to surround large cells (arrows show four examples). Scale bars, $200 \mu \mathrm{m}$.

solubilized; most is present in the $6 \mathrm{~m}$ guanidine- $\mathrm{HCl}$ extract of brain (Fig. 3). The ratio of the amount of T1 antigen extracted by physiological salt compared to the amount extracted by $6 \mathrm{M}$ guanidine- $\mathrm{HCl}$ is 0.18 . That is, only $18 \%$ as much $\mathrm{T} 1$ antigen

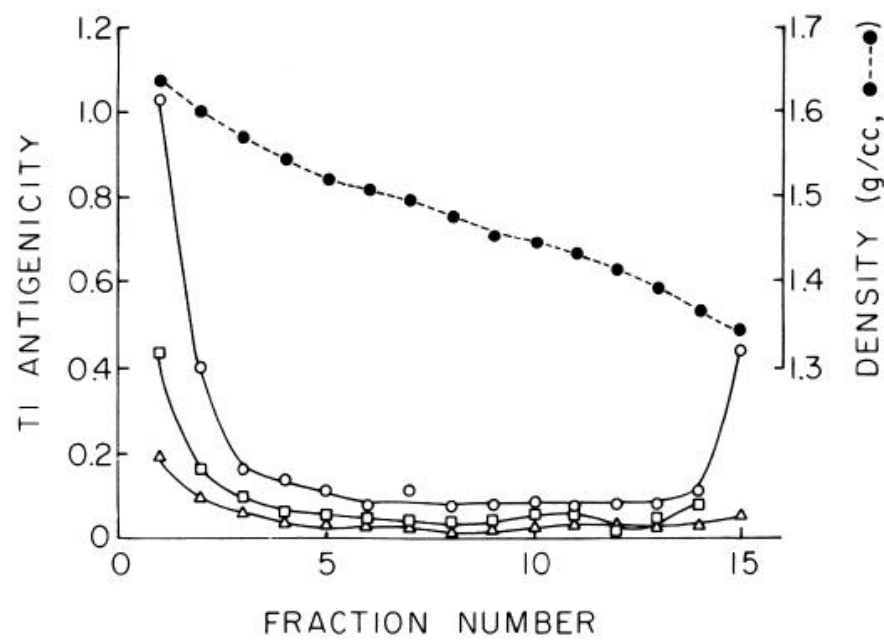

Figure 3. Sedimentation equilibrium of rat brain extracts on $\mathrm{CsCl}$ density gradients. $\mathrm{T} 1$ antigenicity is plotted on the $\mathrm{y}$-axis with fraction number on the $\mathrm{x}$-axis for rat brain extracts. Three consecutive extractions were made of the brain tissue, and the resulting extracts were sedimented in $\mathrm{CsCl}$ : a $0.15 \mathrm{M} \mathrm{NaCl}$ extract (ㅁ), a $1 \%$ Triton X-100 extract $(\triangle)$, and a $6 \mathrm{~m}$ guanidine- $\mathrm{HCl}, 2 \% \mathrm{CHAPS}$ extract (o). The density of each fraction is also shown (๑). Tl antigenicity was measured by dot immunoassay.

is extracted by physiological salt as is extracted by $6 \mathrm{~m}$ guanidine$\mathrm{HCl}$. Similarly, only $14 \%$ as much $\mathrm{T} 1$ antigen is extracted by $1 \%$ Triton $\mathrm{X}-100$ (Table 1 ) as is extracted by $6 \mathrm{~m}$ guanidine$\mathrm{HCl}$. Further, procedures such as increasing the $\mathrm{NaCl}$ concentration to $0.5 \mathrm{M}$ in the Triton X-100 solution, or substituting $2 \%$ CHAPS, $9 \mathrm{~mm}$ deoxycholate, or $60 \mathrm{~mm}$ octyl glucoside for $1 \%$ Triton X-100 do not increase the amount of antigen extracted by the nondenaturing detergent solution (Table 1).

Rat brain $\mathrm{T} 1$ antigen sediments to a density greater than 1.55 gm/cc (Fig. 3, fractions 1 and 2). The T1 antigen in the bottom fraction of the gradient (Fig. 3, fraction 1) may have a density even greater than the density of this fraction $(1.64 \mathrm{gm} / \mathrm{cc})$. The small amount of antigenicity found in fraction 15 (Fig. 3 ) is due to nonspecific binding of the antibody probe, since the IgM control $\mathrm{mAb}$ (MOPC 104E) gives the same signal on dot blot (data not shown).

\section{Isolation of the T1 antigen from rat brain}

When $\mathrm{T} 1$ antigen isolated by sedimentation equilibrium on $\mathrm{CsCl}$ density gradients is chromatographed on DEAE Sephacel, it

Table 1. Extractability of T1 antigen from brain tissue

\begin{tabular}{lllc}
$\begin{array}{l}\text { Sequential } \\
\text { extraction }\end{array}$ & Extraction solutions & Detergents & $\begin{array}{c}\text { T1 } \\
\text { antigen } \\
\text { extracted }\end{array}$ \\
\cline { 2 - 4 } First extraction & Salts & None & 18 \\
Second extraction & $0.15 \mathrm{M} \mathrm{NaCl}$ & $1 \%$ Triton X-100 & 6.3 \\
& $0.5 \mathrm{M} \mathrm{NaCl}$ & $1 \%$ Triton X-100 & 14 \\
& $0.15 \mathrm{M} \mathrm{NaCl}$ & $2 \%$ CHAPS & 11 \\
& $0.15 \mathrm{M} \mathrm{NaCl}$ & 9 mM deoxycholate & 11 \\
Third extraction & $0.15 \mathrm{M} \mathrm{NaCl}$ & 60 mM octyl glucoside & 6.5 \\
\hline
\end{tabular}

${ }^{a}$ Expressed as the percentage of $\mathrm{T} 1$ antigen solubilized by the third extraction. 

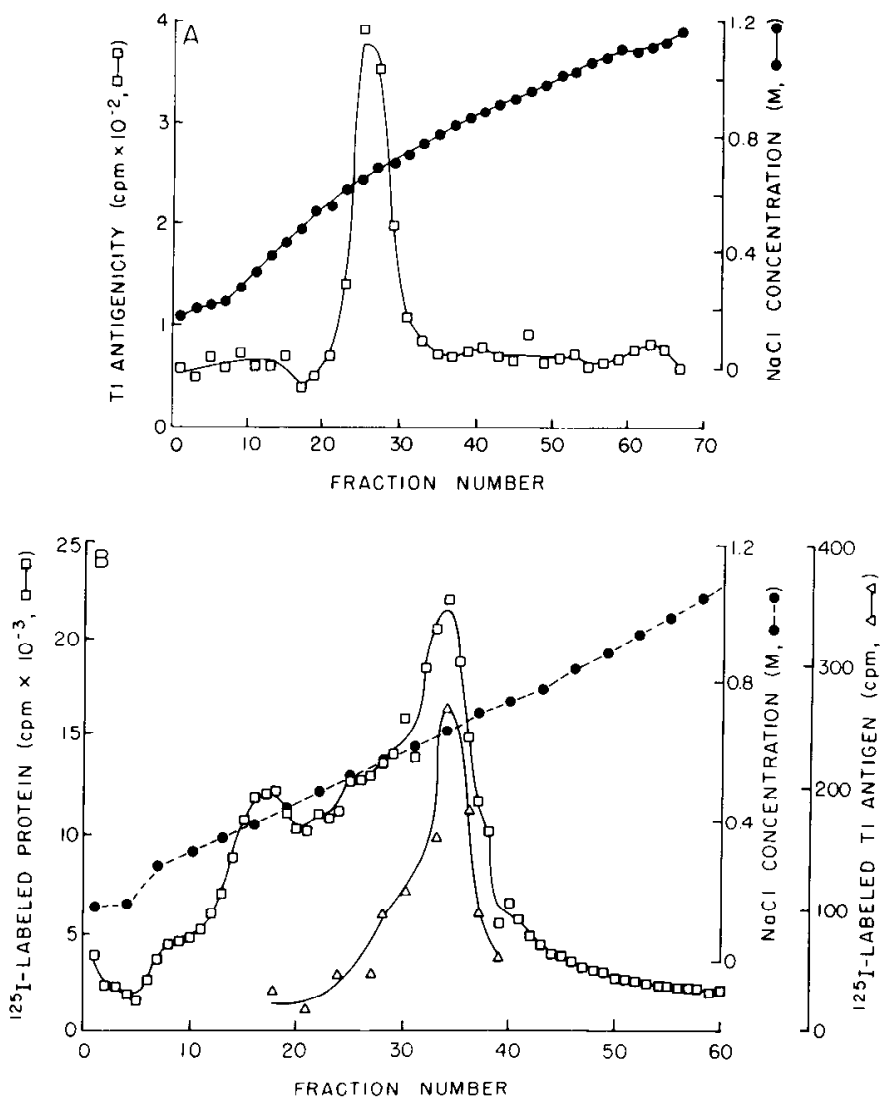

Figure 4. Chromatography of rat brain T1 antigenicity on DEAE Sephacel. $A$. The $\mathrm{T} 1$ antigen-rich fractions resulting from sedimentation of $6 \mathrm{M}$ guanidine- $\mathrm{HCl}, 2 \% \mathrm{CHAPS}$ rat brain extracts on $\mathrm{CsCl}$ gradients (>1.55 gm/ $/ \mathrm{cc}$ ) were subjected to ion exchange chromatography on DEAE Sephacel in $8 \mathrm{M}$ urea/CHAPS, $\mathrm{pH} 4.9$. T1 antigenicity is plotted on the left-hand $y$-axis (ㅁ), fraction number on the $x$-axis, and the eluting salt concentration on the right-hand $y$-axis $(\bullet)$. The DEAE column was eluted with a linear gradient of $0.11-1.4 \mathrm{M} \mathrm{NaCl}$. The peak of $\mathrm{T} 1$ antigenicity eluted at $0.65 \mathrm{M} \mathrm{NaCl}$. T1 antigenicity was measured by dot immunoassay. $B$, Partial purification of the ${ }^{125}$ I-labeled $T 1$ antigen by chromatography on DEAE Sephacel. Proteins present in the $\mathrm{CsCl}$ density fractions enriched for the TI antigen were labeled with ${ }^{125} I$ and chromatographed on DEAE Scphacel under the same conditions as in $A$. Aliquots of selected fractions were immunoprecipitated with the anti$\mathrm{T} 1 \mathrm{mAb}$. Fraction number is plotted on the $x$-axis. Total ${ }^{125}$ I-labeled protein $(\sqcup),{ }^{125}$ I-protein specifically immunoprecipitated by the anti-T1 $\mathrm{mAb}(\triangle)$, and $\mathrm{NaCl}$ concentration $(\bullet)$ are plotted on the $y$-axes. The immunoprecipitated cpm shown on the figure is the difference between the cpm immunoprecipitated by the anti-T $1 \mathrm{mAb}$ and the cpm precipitated by an irrelevant $\mathrm{mAb}$ (anti-SV2). The ${ }^{125} \mathrm{I}$-labeled T1 antigen elutes at $0.64 \mathrm{~m} \mathrm{NaCl}$.

elutes as one peak (Fig. $4 A$ ) at $0.65 \mathrm{~m}( \pm 0.03, \mathrm{SD}) \mathrm{NaCl}$. This behavior suggests that $\mathrm{T} 1$ antigen is a proteoglycan. Due to the presence of sulfates on their glycosaminoglycan side chains, proteoglycans require $>0.3 \mathrm{~m}$ salt to be eluted from DEAE Sephacel at $\mathrm{pH} 5.0$ (Yanagishita et al., 1987).

Western blot analysis of the rat brain $\mathrm{T} 1$ antigen isolated on $\mathrm{CsCl}$ density gradients reveals a single broad band migrating above $400 \mathrm{kDa}$ (Fig. 5, lane 1). No other proteins appear to contain this epitope. In addition, $\mathrm{T} 1$ antigen is a minor component of the $\mathrm{CsCl}$ density fractions (>1.55 girl/cc). We labeled the proteins in these $\mathrm{CsCl}$ fractions with ${ }^{125} \mathrm{I}$ and subjected them to SDS-PAGE. T1 antigen cannot be distinguished in the resulting electrophoretograms (Fig. 5, lanes 4, 5), indicating that it is not prominent in these $\mathrm{CsCl}$ fractions.
To isolate the ${ }^{125}$ I-labeled T1 antigen, we chromatographed these ${ }^{125}$ I-labeled proteins from the $\mathrm{CsCl}$ density gradient on DEAE Sephacel, and then immunoprecipitated the ${ }^{125}$ I-T1 antigen from selected DEAE Sephacel fractions. The elution profile of the DEAE Sephacel column showed several peaks of ${ }^{125} \mathrm{I}-$ labeled protein (Fig. 4B), the first eluting at $0.37 \mathrm{M} \mathrm{NaCl}$ and the last at $0.64 \mathrm{~m} \mathrm{NaCl}$. From our earlier chromatography of the unlabeled $\mathrm{T} 1$ antigen (Fig. 4.A), we expected the ${ }^{125} \mathrm{I}-\mathrm{T} 1$ antigen to elute at about $0.65 \mathrm{M} \mathrm{NaCl}$. This was indeed the case. When we subjected selected fractions to immunoprecipitation with anti-T $1 \mathrm{mAb}$, the last peak contained ${ }^{125} \mathrm{I}-\mathrm{T} 1$ antigenicity (Fig. 4B). We pooled for further analysis these peak fractions, $31-38$, which eluted in the range from $0.61 \mathrm{~m}$ to $0.68 \mathrm{M} \mathrm{NaCl}$. About $60 \%$ of the radioactivity of this pool is immunoprecipitated by the $\mathrm{T} 1 \mathrm{mAb}$.

When we analyze this immunoprecipitated ${ }^{125}$ I-labeled T1 antigen on SDS-PAGE, it appears as a broad band migrating above $400 \mathrm{kDa}$ (Fig. 5, lane 2). No other proteins are seen, and the control precipitation with an irrelevant $\mathrm{mAb}$ shows no precipitation of ${ }^{125}$ I-labeled protein (Fig. 5, lane 3). Further, this ${ }^{125} \mathrm{I}-\mathrm{Tl}$ antigen (Fig. 5, lane 2) has a mobility identical to that of the unlabeled impure antigen detected by Western blots of the $\mathrm{CsCl}$ density gradient fractions (Fig. 5, lane 1). To ensure a precise comparison, we used different lanes of the same SDS polyacrylamide gel for the Western blot of the $\mathrm{CsCl}$ density fractions (Fig. 5, lane 1) and the SDS-PAGE of the immunoprecipitated ${ }^{125}$ I-T1 antigen (Fig. 5, lane 2). From these data, we conclude that the ${ }^{125}$ I-labeled immunopurified $\mathrm{T} 1$ antigen is the same antigen identified in the $\mathrm{CsCl}$ density gradient fractions by Western blot.

\section{The brain $T 1$ antigen is a chondroitin sulfate proteoglycan} with a protein core of $300 \mathrm{kDa}$

The evidence that Tl antigen is a chondroitin sulfate proteoglycan is its sensitivity to glycosaminoglycan lyases. We immunoprecipitated ${ }^{125}$ I-labeled $\mathrm{T} 1$ antigen and digested it without enzyme (Fig. 6, lane A), with chondroitin ABC lyase (Fig. 6, lane C), with keratinases I and II (Fig. 6, lane D), heparitinase (Fig. 6, lane E), and chondroitin $\mathrm{ABC}$ lyase plus keratinases I and II (Fig. 6, lane F). Only chondroitin ABC lyase caused a change in the molecular weight of the protein. The broad band above $400 \mathrm{kDa}$ shifts to a compact molecular species with an $M_{r}$ of $300 \pm 20 \mathrm{kDa}(\mathrm{SD})$. Two minor species are also seen at $450 \pm 30 \mathrm{kDa}(\mathrm{SD})$ and $220 \pm 10 \mathrm{kDa}(\mathrm{SD})$ representing only $5 \% \pm 1 \%(\mathrm{SD})$ and $3 \% \pm 1 \%(\mathrm{SD})$ of the $300 \mathrm{kDa}$ species, respectively. Estimates for these minor species are based on the assumption that the radioactive specific activity, ${ }^{125} \mathrm{I} /$ unit of protein molecular weight, is the same for all three proteins. Comparison of several chondroitin sulfate proteoglycans of known sequence suggests that the radioactive specific activity could vary by a factor of 2 (see Materials and Methods). Thus, the $450 \mathrm{kDa}$ and the $220 \mathrm{kDa}$ proteins might represent $3-7 \%$ and $2-4 \%$ of the total $\mathrm{T} 1$ antigenicity, respectively.

At least $89 \%$ of the $\mathrm{T} 1$ antigenicity present in rat brain is on a chondroitin sulfate proteoglycan with a protein core of 300 $\mathrm{kDa}$. This hypothesis is based on the following data. All T1 antigenicity extracted from brain sediments to high density $(>1.55 \mathrm{gm} / \mathrm{cc}$ ) on $\mathrm{CsCl}$ density gradients (Fig. 3). When these high-density fractions are analyzed by Western blot with anti$\mathrm{T} 1 \mathrm{mAb}$, a single broad band of antigenicity above $400 \mathrm{kDa}$ is seen (Fig. 5, lane 1). Moreover, when the ${ }^{125}$ I-labeled antigen is purified from $\mathrm{CsCl}$ density gradient fractions with DEAE Se- 


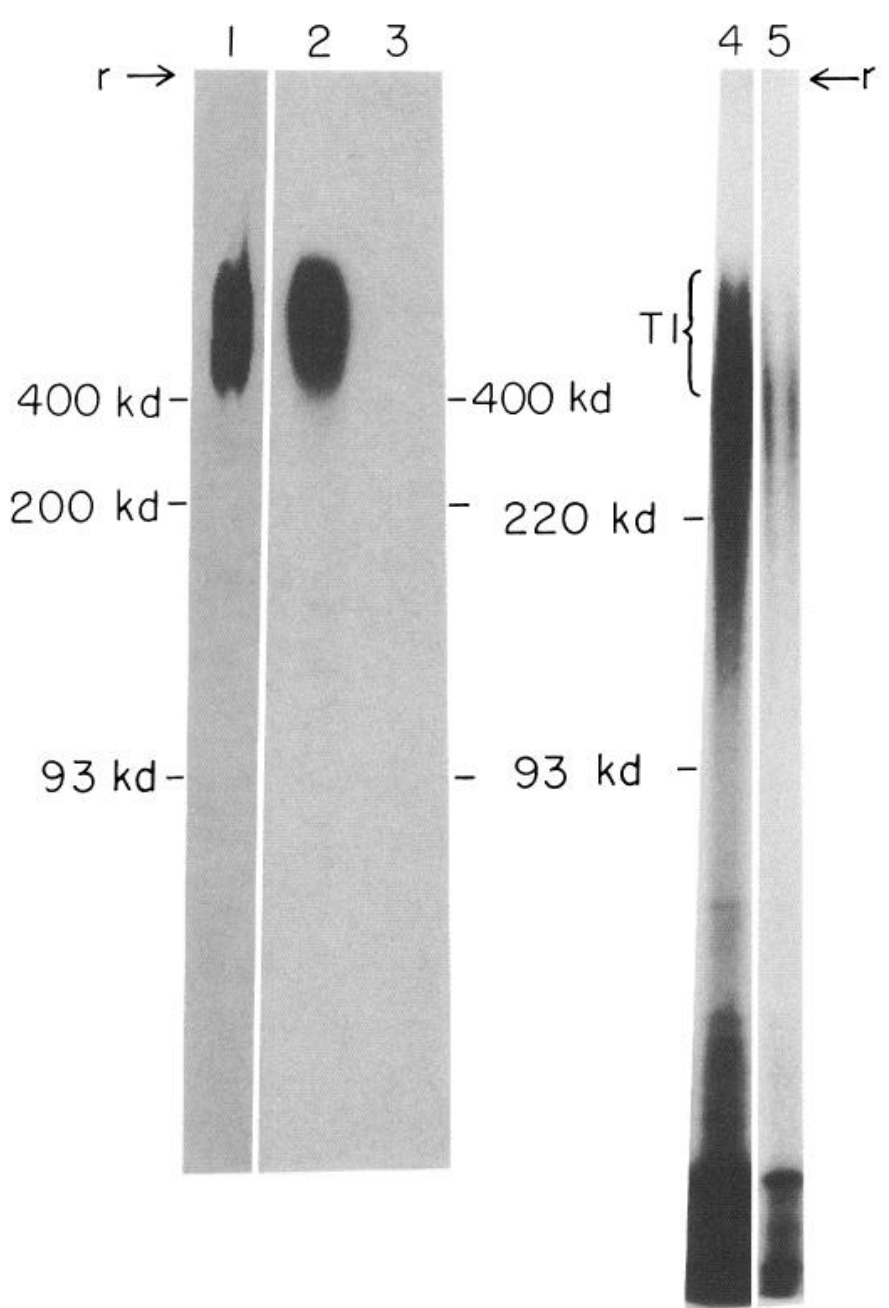

Figure 5. SDS-PAGE comparison of immunopurified ${ }^{125} \mathrm{I}$-labeled T1 antigen with the $\mathrm{T} 1$ antigen as initially extracted from rat brain. The $\mathrm{T} 1$ antigen-enriched fractions from $\mathrm{CsCl}$ density gradients $(>1.55 \mathrm{gm} /$ cc on Fig. 3) were Western blotted, with the anti-T1 mAb (lane 1). These same $\mathrm{CsCl}$ density fractions were labeled with ${ }^{125} \mathrm{I}$ (shown in lanes 4 and 5), the proteoglycans in these fractions were isolated by DEAE Sephacel chromatography (shown in Fig. $4 B$ ), and the ${ }^{125}$ I-T1 antigen was immunoprecipitated with the anti-T1 mAb (lane 2). Immunoprecipitation with an irrelevant $\mathrm{mAb}$ (anti-SV2) shows no precipitation of ${ }_{125}$ I-protein (lane 3). The Western blot of the $\mathrm{T} 1$ antigen from $\mathrm{CsCl}$ gradients (lane I) and SDS-PAGE of the ${ }^{125}$ I-labeled immunoprecipitated $\mathrm{T} 1$ antigen (lane 2) were prepared from different lanes of the same SDS-polyacrylamide gel. The electrophoretic position of the T1 antigen is indicated for lanes 4 and 5 ; lane 5 is a fourfold dilution of the ${ }^{125} \mathrm{I}-$ labeled protein applied to lane 4. $r$ marks the beginning of the running gel.

phacel chromatography and immunoprecipitation, this material has the same electrophoretic mobility on SDS-PAGE as the impure antigen from $\mathrm{CsCl}$ density gradients detected by Western blot (Fig. 5, compare lanes 1 and 2). And finally, after digestion by chondroitin $\mathrm{ABC}$ lyase, the majority (89-95\%) of the ${ }^{125} \mathrm{I}-$ $\mathrm{T} 1$ antigen migrates as a single $300 \mathrm{kDa}$ molecular species (Fig. 6 , lanes $\mathrm{C}$ and F).

The $T 1$ antigen is distinct from the large ECM chondroitin sulfate proteoglycans, aggrecan and versican

Aggrecan is a large space-filling chondroitin sulfate/keratan sulfate proteoglycan present at high concentration in cartilage (Hascall and Hascall, 1981; Doege et al., 1987). Versican is another

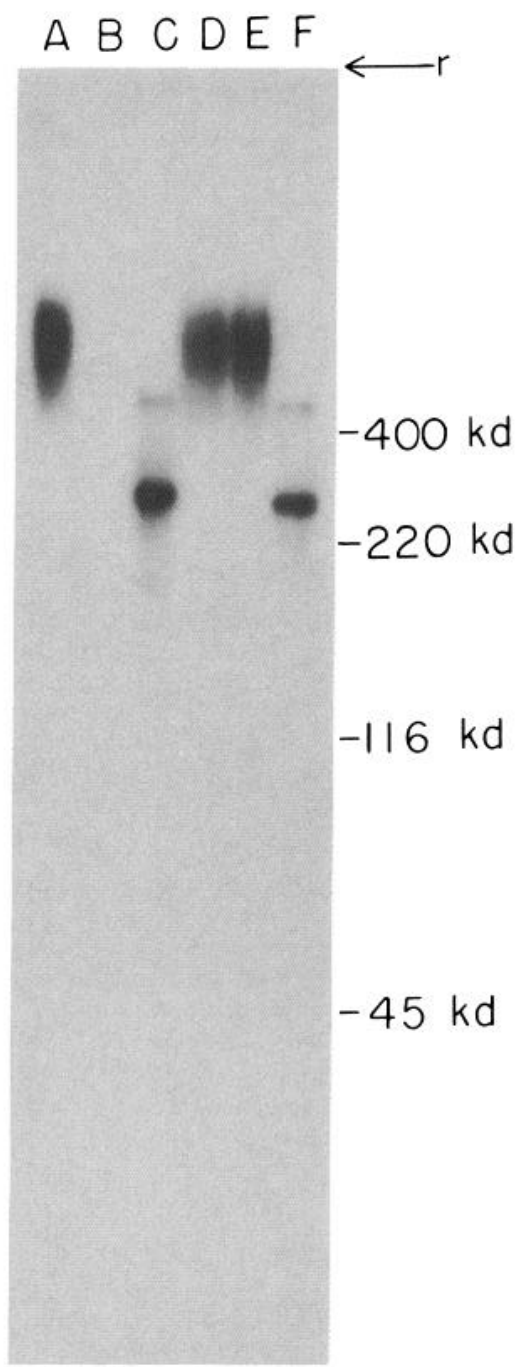

Figure 6. Digestion of immunoprecipitated ${ }^{125}$ I-labeled rat brain $\mathrm{T} 1$ antigen with glycosaminoglycan lyases. ${ }^{125}$ I-labeled $\mathrm{Tl}$ antigen was immunoprecipitated with the anti-T1 mAb (lanes $A, C-F$ ), or a control $\mathrm{mAb}$, anti-SV4 (lane $B$ ). Immunoprecipitated ${ }^{125}$ I-labeled $\mathrm{T} 1$ antigen was exposed to no enzyme $(A, B)$, chondroitin $\mathrm{ABC}$ lyase $(C)$, keratinases I and II $(D)$, heparitinase $(E)$, or chondroitin $\mathrm{ABC}$ lyase and keratinases I and II $(F)$. The immunoprecipitation procedure was identical to that used in Figure 5 (lane 2). One major protein band is seen after digestion with chondroitin $\mathrm{ABC}$ lyase at $300 \mathrm{kDa}$. Two minor protein species are seen at $450 \mathrm{kDa}$ and $220 \mathrm{kDa}$ after chondroitin $\mathrm{ABC}$ lyase that represent only $5 \%$ and $3 \%$ of the $300 \mathrm{kDa}$ protein core. $r$ marks the beginning of the running gel. To ensure that all of the glycosaminoglycan lyases were active, parallel reactions containing the appropriate glycosaminoglycan were performed and analyzed by cellulose acetate electrophoresis.

large chondroitin sulfate space-filling proteoglycan. The cDNAs of both proteoglycans have been cloned and sequenced (Doege et al., 1987; Zimmermann and Ruoslahti, 1989). Both of these proteins contain regions of similar sequence near their $\mathrm{N}$-terminal and C-terminal (Zimmermann and Ruoslahti, 1989). Other regions of these proteins are not homologous.

A 15 amino acid sequence, CDAGWLADQTVRYPI, present in the hyaluronate binding region of aggrecan (at residues 199_ 213 ) is identical in aggrecan (Doege et al., 1987) and versican (Zimmermann and Ruoslahti, 1989). This sequence has been identified in human versican (Zimmermann and Ruoslahti, 1989), and in the aggrecan of rat (Doege et al., 1987), human (Doege et al., 1991), and cow (Antonsson et al., 1989). It has 
A)

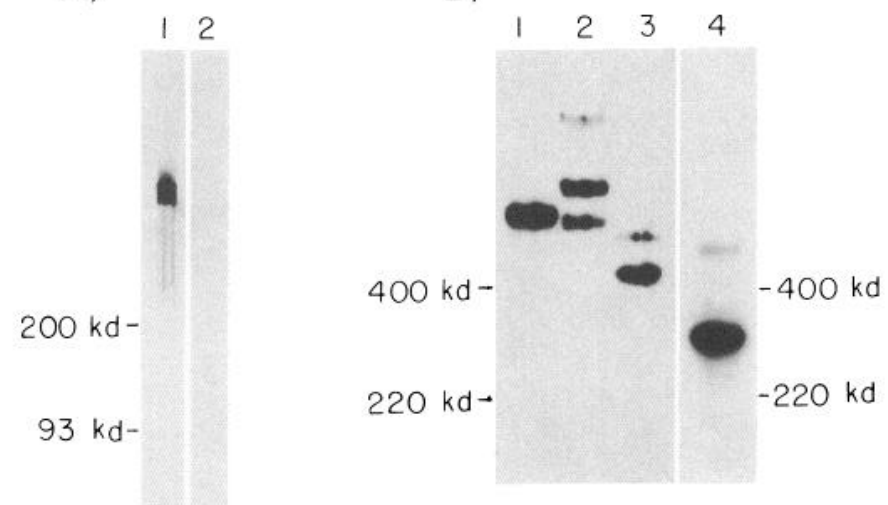

$22 \mathrm{kd}-$

Figure 7. SDS-PAGE comparison of the $\mathrm{T} 1$ antigen core protein to proteoglycan core proteins identified by the a $-\mathrm{HAL}$ antiserum. $A$, à-HAL antibodies specifically react with bovine aggrecan. The A1DI fraction from cartilage, which is enriched in aggrecan, was subjected to SDS-PAGE, immunoblotted, and probed with affintiy-purified å-HAL antibodies (lane 1 ). When the 15 amino acid peptide CDAGWLADQTVRYPI was mixed with the antibodies before incubation with the aggrecan blot, no binding of the a-HAL to aggrecan is seen (lane 2). $B$, The mobility of the T1 proteoglycan core protein is distinct from proteoglycan cores identified by the a-HAL antibodies. ${ }^{125}$ I-labeled T1 proteoglycan was immunoprecipitated by the anti-T1 mAb, digested with chondroitin ABClyase, and subjected to SDS-PAGE (lane 4) as described for Figure 6, lane C. On the same SDS-polyacrylamide gel, we electrophoresed several unlabeled proteoglycan samples that had been digested with glycosaminoglycan lysases (lanes $1-3$ ). These three lanes of the SDS gel were immunoblotted and probed with the a-HAL antibodies. They contain partially purified aggrecan digested with chondroitin ABClyase/keratinase (lane 1), secreted smooth muscle cell proteoglycans digested with chondroitin ABClyase (lane 2), and Triton X100 -extracted rat brain proteoglycans digested with chondroitin ABClyase (lane 3). The ${ }^{125}$ I-labeled T1 proteoglycan core (lane 4) was visualized by autoradiography. The exact alignment of lanes $1-3$ with lane 4 was made using the positions of the $A$ and $B$ chains of laminin electrophoresed in the lanes adjacent to $I$ and 4 .

also been found in a hyaluronic acid-binding protein associated with glial cells from brain (Perides et al., 1989). We made a peptide containing this 15 amino acid sequence and produced a rabbit antiserum that recognizes it. We purified these antibodies (̊̊-HAL) on a column of epoxy-activated Sepharose to which the 15 amino acid peptide was attached. The a - HAL antibodies recognized chondroitin ABClyase/keratinase-digest-

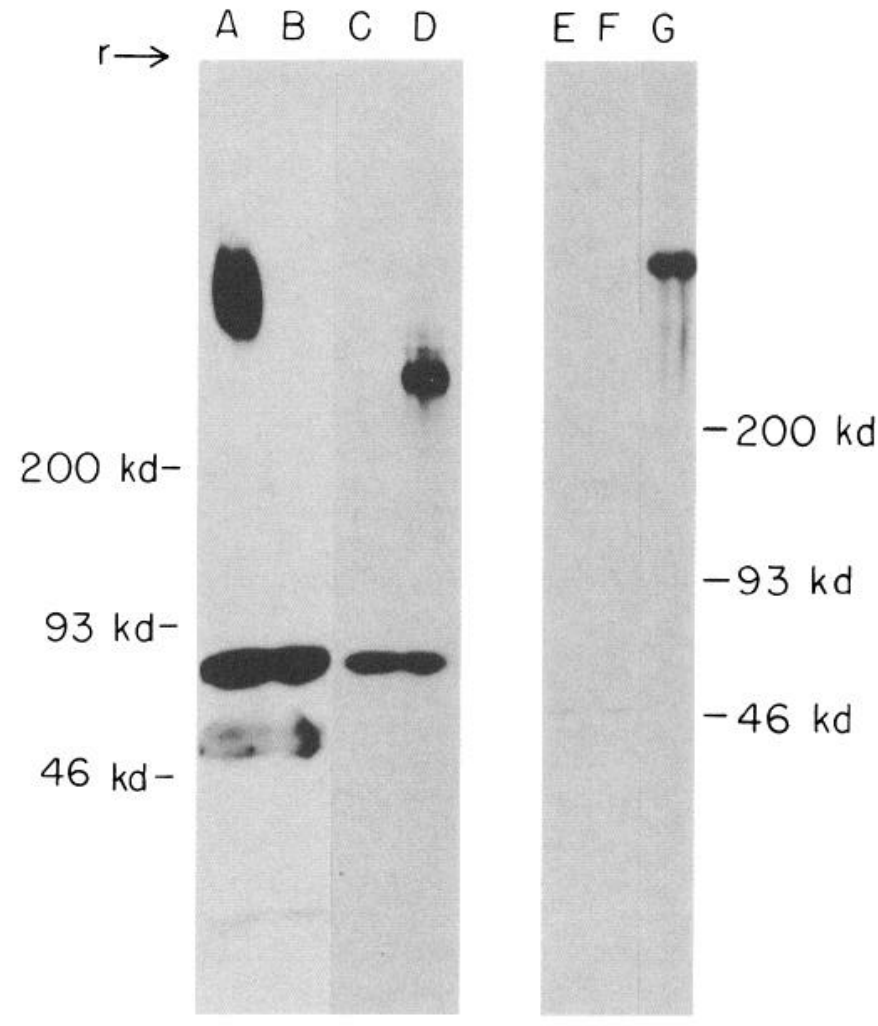

Figure 8. a-HAL antibodies do not react with the T1 antigen. Unlabeled $\mathrm{T} 1$ antigen was immunoprecipitated with the anti-T1 mAb, incubated with either no enzyme (lanes $A, C$, and $E$ ) or chondroitin ABClyase (lanes $B, D$, and $F$ ), and subjected to Western blot. These Western blots were probed with anti-T1 mAb (lanes $A$ and $B$ ), antistubs mAbs (lanes $C$ and $D$ ), and å-HAL antibodies (lanes $E$ and $F$ ). Aggrecan digested with chondroitin ABClyase/keratinase was included on the Western blot probed with â-HAL antibodies (lane $G$ ). For lanes $A-D$, the proteins stained between 46 and $93 \mathrm{kDa}$ are the mouse immunoglobulin heavy chains (used for the immunoprecipitation), which are stained with the anti-mouse immunoglobulin secondary antibodies. In lanes $E$ and $F$, the anti-rabbit immunoglobulin secondary antibodies, used to detect the a-HAL antibodies, do not react with the mouse heavy chains. $A$ and $B$ are darker exposures than $C$ and $D . r$ marks the beginning of the running gel.

ed aggrecan in the A1D1 fraction of bovine cartilage on a Western blot (Fig. 7A, lane 1). Preincubation of å-HAL antibodies with the 15 amino acid peptide prevented å-HAL antibodies from binding to aggrecan on the Western blot (Fig. 7A, lane 2). The å-HAL antibodies also recognize three chondroitin sulfate proteoglycan core proteins made by monkey smooth muscle cells in culture (Fig. $7 B$, lane 2 ). These cells are known to produce large amounts of versican (Schonherr et al., 1991).

Table 2. Comparison of the T1 and a-HAL proteoglycans

\begin{tabular}{|c|c|c|}
\hline Properties & $\mathrm{T} 1$ proteoglycan & å-HAL proteoglycans \\
\hline MW of core proteins & $300 \mathrm{kDa}$ & $400 \mathrm{kDa} / 470 \mathrm{kDa}$ \\
\hline Extraction conditions & 6 м Guanidine- $\mathrm{HCl}$ & $\begin{array}{l}1 \% \text { Triton } \mathrm{X}-100 \\
(\text { some by } 0.15 \mathrm{M} \mathrm{NaCl} \text { ) }\end{array}$ \\
\hline Density on $\mathrm{CsCl}$ gradients & $>1.55 \mathrm{gm} / \mathrm{cc}$ & $<1.44 \mathrm{gm} / \mathrm{cc}$ \\
\hline Elution from DEAE Sephacel & $0.65 \mathrm{M} \mathrm{NaCl}$ & $0.55 \mathrm{M} \mathrm{NaCl}$ \\
\hline $\mathrm{T} 1$ antigenicity & Present & Absent \\
\hline å-HAL reactivity & Absent & Present \\
\hline
\end{tabular}


Using the å-HAL antibodies, we have looked for brain chondroitin sulfate proteoglycans that contain the 15 amino acid sequence. After chondroitin $\mathrm{ABC}$ lyase digestion, we find only two core proteins that react with the a-HAL and migrate on SDS-PAGE in a molecular weight range similar to the T1 proteoglycan (Fig. 7, lane 3 ). These core proteins migrate like proteins with molecular weights of about $410 \pm 20 \mathrm{kDa}$ (SD) and $480 \pm 20 \mathrm{kDa}$ (SD). However, these chondroitin sulfate proteoglycans differ from the brain T1 proteoglycan (Table 2). When partially purified brain å-HAL proteoglycan core proteins are electrophoresed on the same SDS-polyacrylamide gel as the brain ${ }^{125} \mathrm{I}-\mathrm{T} 1$ proteoglycan core protein (Fig. $7 \mathrm{~B}$, compare lanes 3 and 4), the å-HAL proteoglycan cores have different mobilities than the T1 proteoglycan core protein $(300 \mathrm{kDa})$. Additionally, the a -HAL brain proteoglycans differ from the brain T1 proteoglycan in the following ways. (1) The å-HAL brain proteoglycans are extracted from brain tissue primarily by $1 \%$ Triton $\mathrm{X}-100$ (some by $0.15 \mathrm{M} \mathrm{NaCl}$ alone), whereas the majority of the T1 antigen requires denaturing conditions. (2) The å-HAL proteoglycans sediments to a density of $<1.44 \mathrm{gm} / \mathrm{cc}$ on $\mathrm{CsCl}$ density gradients, while the $\mathrm{T} 1$ proteoglycan sediments to $>1.55$ gm/cc. (3) The å-HAL proteoglycans elute from DEAE Sephacel (pH 4.9) at $0.55 \mathrm{M} \mathrm{NaCl}$, but the $\mathrm{T} 1$ proteoglycan requires 0.65 $\mathrm{M} \mathrm{NaCl}$. (4) The å-HAL proteoglycans do not react with the anti- $\mathrm{T} 1 \mathrm{mAb}$. The $\mathrm{CsCl}$ density gradient fractions (of the Triton $\mathrm{X}-100$ brain tissue extract) that are enriched in the å-HAL brain proteoglycans (density, $<1.44 \mathrm{gm} / \mathrm{cc}$ ) show no $\mathrm{T} 1$ antigenicity by dot blot (Fig. 3). When these fractions are probed on a Western blot, we also see no reactivity (data not shown).

The T1 proteoglycan does not contain the 15 amino acid sequence common to aggrecan and versican. We find that the å-HAL antibodies do not react with the T1 proteoglycan core protein on Western blots. Unlabeled T1 proteoglycan was partially purified by chromatography on DEAE Sephacel, immunoprecipitated with the anti-T $1 \mathrm{mAb}$, incubated with and without chondroitin ABC lyase, and Western blotted (Fig. 8). When these Western blots were probed with the â-HAL antibodies, no reaction was seen, either with the $\mathrm{T} 1$ proteoglycan core protein (Fig. 8, lane F) or with the intact proteoglycan (Fig. 8, lane E). Aggrecan is detected on this same Western blot (Fig. 8, lane G). Although the T1 antigen does not react with the å-HAL antibodies, the $\mathrm{T} 1$ proteoglycan core protein is easily detected (Fig. 8, lane D) with the anti-chondroitin sulfate "stubs" mAbs (2B6 and 3B3). These mAbs recognize the small piece of chondroitin sulfate chain that remains attached to the protein core after $\mathrm{ABC}$ lyase digestion. The $\mathrm{ABC}$ lyase digestion creates an unsaturated bond that is the epitope that the anti-chondroitin sulfate "stubs" mAbs recognizes (Caterson et al., 1987). The undigested $\mathrm{T} 1$ proteoglycan is stained by the anti-T1 mAb on the blot (Fig. 8, lane A).

As mentioned earlier, the T1 epitope is removed from the proteoglycan by chondroitin ABC lyase digestion. Immunoprecipitated unlabeled $\mathrm{T} 1$ antigen is easily detected on a Western blot probed with the anti-T1 mAb (Fig. 8, lane A). After digestion of the immunoprecipitated $\mathrm{T} 1$ antigen with chondroitin $\mathrm{ABCase}$, the core protein is not stained with the anti-T1 mAb (Fig. 8, lane B). The protein core is, however, detected by the anti-"stubs" antibody (Fig. 8, lane D).

The brain $T 1$ antigen appears to be in a disulfide-stabilized complex with two other proteins

When the ${ }^{125} \mathrm{I}$-labeled $\mathrm{T} 1$ antigen (isolated by DEAE chromatography) is immunoprecipitated by the $\mathrm{T} 1 \mathrm{mAb}$ with prior

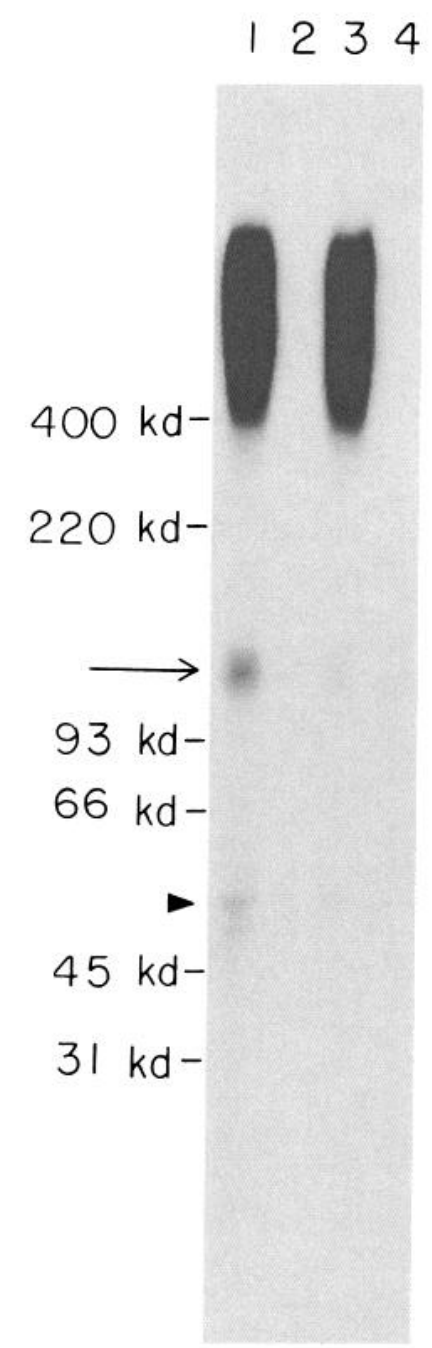

Figure 9. The T1 antigen is disulfide linked to two proteins. ${ }^{125}$ I-labeled $\mathrm{T} 1$ antigen isolated on DEAE Sephacel was immunoprecipitated with the anti-T1 mAb after boiling in SDS (lane I) or boiling in SDS under reducing conditions (lane 3 ) and subjected to SDS-PAGE. Control precipitations of the ${ }^{125}$ I-labeled $\mathrm{Tl}$ antigen with an irrelevant $\mathrm{mAb}$ (antiSV2) after SDS (lane 2) or SDS under reducing conditions (lane 4) were also performed. The immunoprecipitated ${ }^{125}$ I-labeled $\mathrm{T} 1$ antigen was dissociated from $\mathrm{mAb}$ by boiling in SDS under reducing conditions before SDS-PAGE. If the T1 antigen is pretreated with SDS under nonreducing conditions (lane 1), a $119 \mathrm{kDa}$ (arrow) and a $53 \mathrm{kDa}$ protein (arrowhead) are immunoprecipitated along with the $\mathrm{T} 1$ antigen. These proteins are not immunoprecipitated (lane 3 ) when the T1 antigen is pretreated with SDS under reducing conditions.

exposure to SDS under nonreducing conditions, two proteins of $119 \mathrm{kDa}$ and $53 \mathrm{kDa}$ are specifically immunoprecipitated along with the T1 antigen (Fig. 9, lane 1). When the T1 antigen is boiled in SDS under reducing conditions to break disulfide bonds before immunoprecipitation, only the ${ }^{125} \mathrm{I}$-labeled T1 antigen is immunoprecipitated (Fig. 9, lane 3; see also Figs. 5-8). The presence of a reducing agent during the SDS treatment decreases by $70 \%$ the amount of $119 \mathrm{kDa}$ and $53 \mathrm{kDa}$ proteins immunoprecipitated with the $\mathrm{T} 1$ antigen (Fig. 9, compare lanes 1 and 3). These $119 \mathrm{kDa}$ and $53 \mathrm{kDa}$ proteins are specifically immunoprecipitated, and are not bound by an irrelevant $\mathrm{mAb}$ (Fig. 9, lane 2). However, these two proteins are not themselves bound by the anti-T1 mAb, since they are not immunoprecipitated after reduction (Fig. 9, lane 3) and the $119 \mathrm{kDa}$ and 53 $\mathrm{kDa}$ proteins are not stained by the anti-T1 mAb on Western 

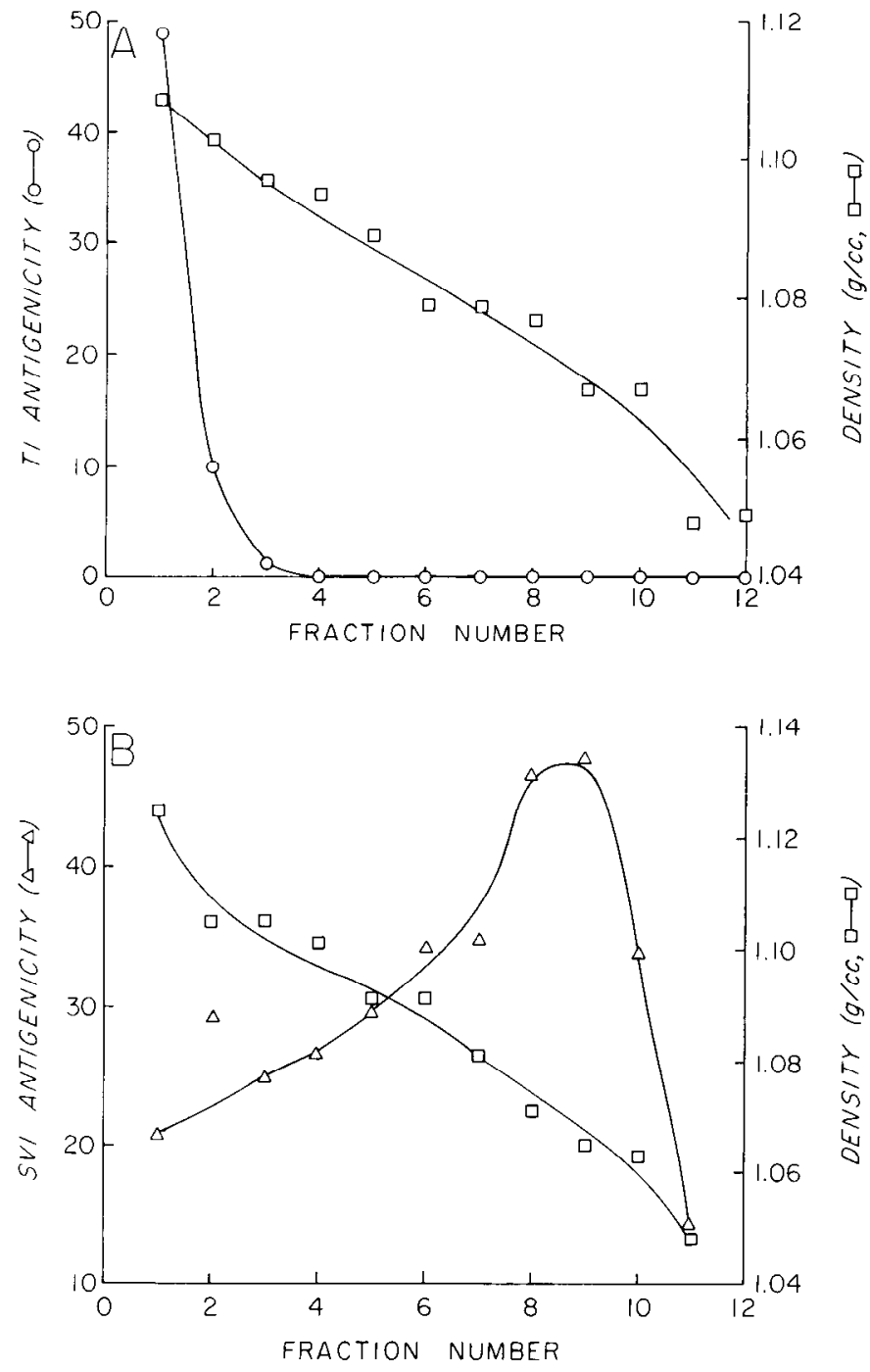

Figure 10. Attempt at reconstitution of the $\mathrm{T} 1$ antigen into a liposome bilayer. We attempted to reconstitute the $\mathrm{Tl}$ antigen $(A)$ or an integral membrane synaptic vesicle proteoglycan $(B)$ into liposomes, and float these liposomes to their equilibrium density on sucrose gradients. Liposomes formed in the presence of the isolated $\mathrm{T} 1$ antigen or solubilized synaptic vesicle proteoglycan (SV1) were applied to 5-35\% sucrose gradients and centrifuged for $20 \mathrm{hr}$. To apply the liposomes to the sucrose gradients, the liposome solution was made $45 \%$ sucrose and layered under the sucrose gradient. After centrifugation, $0.9 \mathrm{ml}$ fractions were collected and assayed for $\mathrm{T} 1(0)$ or SV1 $(\triangle)$ antigenicity by dot blot. These antigenicities and sucrose densities (ㅁ) are plotted on the $y$-axis and fraction number on the $x$-axis. The SV1 proteoglycan is readily incorporated into liposomes and floats to a density of $1.065 \mathrm{gm} / \mathrm{cc}(B)$ The $\mathrm{T} 1$ antigen remains at the bottom of the gradient, indicating no association with liposomes $(A)$. If the nondenaturing detergent CHAPS is added to the sucrose gradient before the centrifugation, no shift in the density of the SV1 proteoglycan is seen (data not shown).

blot (Fig. 5, lane 1). The most likely explanation is that these two proteins are linked by disulfide bonds to the $\mathrm{T} 1$ antigen. $\mathrm{A}$ less likely alternative is that intramolecular disulfide bonds stabilize an extremely strong intermolecular noncovalent interaction between these proteins and the Tl antigen. The fact that not all of these proteins are released by SDS treatment under reducing conditions suggests either that the interactions between these proteins are difficult to break, or that they are capable of reforming under the nondenaturing conditions of immunoprecipitation. The molecular weight of the $53 \mathrm{kDa}$ band is uncertain, since immunoprecipitation produces a large amount of unlabeled immunoglobulin heavy chain that migrates close to the ${ }^{125}$ I-labeled protein, distorting the band.

The complex of $\mathrm{Tl}$ antigen and these two disulfide-linked proteins chromatographs like a protein of $800 \mathrm{kDa}$ when subjected to gel filtration. The ${ }^{125}$ I-labeled $\mathrm{T} 1$ antigen partially purified by chromatography on DEAE Sephacel (as in Fig. 4) was chromatographed on Sephacryl S-500 under denaturing, but nonreducing, conditions. The Tl antigen was identified in the elution volume by immunoprecipitation. The $\mathrm{T} l$ antigen complex was found to elute at the same volume as intact laminin, which has an $M_{r}$ of $800 \mathrm{kDa}$ (data not shown).

\section{The $T 1$ antigen and its disulfide-linked proteins do not have the properties expected for a membrane-anchored protein}

As dcmonstratcd previously by immunocytochemistry, rat brain $\mathrm{T} 1$ antigen is found in both gray and white matter. This antigenicity can be seen outlining Purkinje cells in the cerebellum and large cells in the hippocampus. However, the isolated antigen and its disulfide-linked proteins do not have the properties of a membrane protein. (1) As discussed previously, unlike an integral membrane protein (Helinius and Simons, 1975), little of the $\mathrm{T} 1$ antigen is extracted by the nondenaturing detergents; the antigen requires guanidine- $\mathrm{HCl}$ for extraction. (2) The isolated $\mathrm{T} 1$ antigen with its disulfide-linked proteins does not associate with liposomes unlike an integral membrane protein.

The T1 antigen does not become reconstituted into the lipid bilayer of liposomes. Such reconstitution has been used as a criterion to determine whether a protein is an integral membrane protein (Kjellen et al., 1981; Rapraeger and Bernfield, 1985). We formed liposomes in the presence of either partially purified T1 antigen or of a solubilized integral membrane synaptic vesicle proteoglycan, SV1 (Carlson and Kelly, 1983; Carlson et al., 1986; Carlson, 1989). The liposomes were then layered under a sucrose gradient and centrifuged to equilibrium. When the resulting gradients were assayed for $\mathrm{T} 1$ or $\mathrm{SV} 1$ antigenicity (Fig. $10, A$ and $B$, respectively), the $\mathrm{T} 1$ antigen remained at the bottom of the gradient, while the SV1 proteoglycan floated to a density of $1.068 \mathrm{gm} / \mathrm{cc}$, similar to that of free liposomes, 1.055 \pm 0.009 (Carlson et al., 1986). Thus, the SV1 proteoglycan became incorporated into the lipid bilayer of the liposome, as expected for an integral membrane protein (Kjellen et al., 1981). In contrast, the T1 antigen failed to associate with liposomes, and thus did not become reconstituted into the lipid bilayer.

The failure of the $\mathrm{T} 1$ antigen to become incorporated into liposomes suggests that this proteoglycan does not have a hydrophobic domain that can intercalate into a bilayer. Alternatively, it is possible that the denaturing conditions $(6 \mathrm{M}$ guanidine- $\mathrm{HCl}$ or $8 \mathrm{~m}$ urea) might have irreversibly denatured the proteoglycan. The liposomes were formed from a solution containing $8 \mathrm{~m}$ urea and $2 \%$ cholate in which the proteins should have unfolded. The chaotropic agent and the detergent were removed by dialysis in the presence of phospholipids. Upon removal of a chaotropic agent, a membrane spanning domain might fold in such a way that it became inaccessible to phospholipids during formation of a liposome bilayer. However, we did not find it to be the case with a known integral membrane proteoglycan, SV 1. This integral membrane proteoglycan, which was subjected to the same denaturing conditions as the $\mathrm{Tl}$ antigen, was quantitatively reconstituted into liposomes (Fig. 10B). This method has also been used successfully with other integral membrane proteoglycans, such as syndecan (Rapraeger and Bernfield, 1983, 1985), after similar exposure to chaotropic agents. 


\section{Discussion}

$\mathrm{T} 1$ antigen is a large chondroitin sulfate proteoglycan in adult rat brain. Chondroitin $\mathrm{ABC}$ lyase digestion of the $\mathrm{T} 1$ antigen reveals a protein core of $300 \mathrm{kDa}$ as measured by SDS-PAGE. This proteoglycan containing the $\mathrm{T} 1$ antigen forms a disulfidestabilized complex with two other proteins of molecular weights $119 \mathrm{kDa}$ and $53 \mathrm{kDa}$. These three proteins are probably linked directly by intermolecular disulfide bonds, although they could be linked by extremely strong noncovalent interactions stabilized with intramolecular disulfide bonds. Immunocytochemically, the $\mathrm{T} 1$ antigen is widely distributed in the brain, in both gray and white matter. TI antigenicity surrounds large cells, such as Purkinje cells in the cerebellum. No T1 antigenicity is seen inside thesc cells. The $\mathrm{T} 1$ antigen must be bound tightly in a large insoluble structure, since denaturing conditions are required to solubilize this proteoglycan from the tissue. However, the requirement for denaturing conditions is not a property of the proteoglycan itself, since this purified proteoglycan is soluble in nondenaturing conditions (data not shown). Presumably, T1 antigen is bound to other proteins in this structure.

That the proteoglycan has an extracellular location is indicated by the presence of disulfide bonds in the $\mathrm{T} 1$ antigen and by the behavior of this antigen during extraction from brain tissue. It is not likely that the proteoglycan is present in the cytosol or in an intravesicular compartment. Proteins with disulfide linkages are found only extracellularly or intravesicularly, but not in the cytosol. Reducing conditions prevail in the cytosol (Alberts et al., 1989). Thus, the Tl antigen must be present either extracellularly or in a vesicular compartment. However, it is unlikely that the $\mathrm{T} 1$ antigen is sequestered in a vesicular compartment, since conditions that readily solubilize membranes and membrane proteins, like treatment with nondenaturing detergents (Helinius and Simons, 1975; Brown and Rose, 1992), do not solubilize the majority of T1 antigenicity.

The requirement for denaturing conditions to extract the majority of $\mathrm{T} 1$ antigen from brain is similar to that for ECM components in other tissues. For example, the large chondroitin sulfate proteoglycan aggrecan requires denaturing conditions to be extracted from cartilage (Hascall and Kimura, 1982; Heinegard and Sommarin, 1987); type IV collagen (Timpl et al., 1979) or a heparan sulfate proteoglycan (Paulsson, 1987) needs denaturing conditions for extraction from basement membranes. These proteins are multivalent components of very large extracellular macromolecular complexes. Solubilization of such components from these matrices may require the breaking of several noncovalent interactions between the macromolecules. In the case of type IV collagen, disulfide bonds need to be broken as well (Timpl et al., 1979). The fact that similar denaturing conditions are required for extraction of the $\mathrm{T} 1$ antigen suggests that this proteoglycan may be part of a large extracellular structure in the brain, such as an ECM.

Explanations for the insolubility of the $\mathrm{T} 1$ antigen other than association with ECM are inconsistent with the properties of the $\mathrm{T} 1$ antigen. For example, one might maintain the hypothesis that the necessity for denaturing conditions is due to a transmembrane linkage of the $\mathrm{T} 1$ antigen to cytoskeleton. The T1 antigen or the disulfide-linked proteins might be transmembrane proteins, or this $\mathrm{T} 1$ antigenic complex might be bound to a transmembrane protein. However, these possibilities are unlikely for the following reasons. (1) The isolated Tl antigen (complexed with the smaller disulfide-linked proteins) does not have the properties of a transmembrane protein; the $T 1$ antigen is not incorporated into liposomes. (2) Transmembrane proteins known to be linked to the cytoskeleton are solubilized by Triton $\mathrm{X}-100$ in physiological salt solutions. ACh receptor (Deutsch and Raftery, 1979; Froehner, 1986; Phillips et al., 1991), Na,KATPase (Nelson and Hammerton, 1989), Band 3 of the red blood cell (Sheetz, 1979), and the proteoglycan syndccan (Rapraeger et al., 1987) all are transmembrane proteins linked to the cytoskeleton. These proteins are solubilized by Triton X-100 in amounts $50-90 \%$ of the total under these conditions. By contrast, under the same conditions only about $11 \%$ of the total $\mathrm{T} 1$ antigen is solubilized. The $\mathrm{T} 1$ antigen may be linked to a plasma membrane protein, but this linkage alone is unlikely to explain the requirement of denaturing conditions for extraction from brain.

The association of the $\mathrm{Tl}$ antigen with the Purkinje cell surface is consistent with other reports of ECM in the mammalian CNS. Using a Golgi impregnation method with both light and electron microscopy, Atoji et al. (1989) report perineuronal nets of ECM that cover some or all of the nerve cell bodies and dendrites in the superior olivary nuclei. Similarly, Zaremba et al. (1989) found a large chondroitin sulfate proteoglycan, Cat301 , covering the surface of motor neuron cell body in a latticework of immunoreactivity. Like the T1 antigen, much of the Cat-301 proteoglycan requires denaturing conditions to be solubilized from the CNS. However, unlike the T1 antigen, Cat301 has a restricted distribution in the brain and is present only on certain neurons (Hockfield et al., 1983). Cat-301 is therefore probably not a general component of CNS ECM.

The majority (89-95\%) of the T1 antigenicity in brain is present on a chondroitin sulfate proteoglycan with a core protein of $300 \mathrm{kDa}$. A small amount of T1 antigen is present on chondroitin sulfate proteoglycans with cores of $450 \mathrm{kDa}(3-7 \%)$ and $220 \mathrm{kDa}(2-4 \%)$. At present, we do not know relationship between the $300 \mathrm{kDa}$ protein core and these minor protein cores. The $450 \mathrm{kDa}$ proteoglycan may be a precursor of the $300 \mathrm{kDa}$ protein, an alternately spliced form of the $300 \mathrm{kDa}$ protein, or unrelated to it. The $220 \mathrm{kDa}$ protein may also be unrelated, an alternately spliced form, or a product of proteolysis of the 300 $\mathrm{kDa}$ core.

T1 antigen from brain has a buoyant density greater than 1.55 $\mathrm{gm} / \mathrm{cc}$ (Fig. 3). This result is similar to that for the large cartilage proteoglycan aggrecan, which is composed of $85-95 \%$ glycosaminoglycan and other oligosaccharides and which sediments to a density greater than $1.55 \mathrm{gm} / \mathrm{cc}$ (Hascall and Kimura, 1982; Heinegard and Sommarin, 1987). The electric organ chondroitin sulfate/keratan sulfate proteoglycan PG-1000, which is about $85 \%$ glycosaminoglycan (Carlson and Wight, 1987), sediments to a density of $>1.5 \mathrm{gm} / \mathrm{cc}$ (Iwata and Carlson, 1991). Small proteoglycans and non-glycosaminoglycan-containing proteins have buoyant densities in $\mathrm{CsCl}<1.44 \mathrm{gm} / \mathrm{cc}$ (Heinegard and Sommarin, 1987). Presumably, the high buoyant density of the $\mathrm{T} 1$ antigen from brain indicates that it is heavily glycosylated.

The $\mathrm{T} 1$ antigen appears to be distinct from other chondroitin sulfate proteoglycans found in the brain. Tl antigen does not contain the CDAGWLADQTVRYPI amino acid sequence present in aggrecan and versican. This is indicated by the lack of reactivity of $\mathrm{T} 1$ antigen with å-HAL antiserum. We have found that several large proteoglycans in rat brain do contain this 15 amino acid sequence, but these proteoglycans have several properties distinct from the $\mathrm{T} 1$ antigen (Table 2). The $\mathrm{T} 1$ protcoglycan is also distinct from $\mathrm{NG} 2$, a $300 \mathrm{kDa}$ chondroitin sulfate proteoglycan (Nishiyama et al., 1991). NG2 is an integral membrane proteoglycan that is associated with smooth proto- 
plasmic astrocytes in adult rat cerebellum (Levine and Card, 1987). This distribution is quite different from that in the $T 1$ proteoglycan. Finally, the $\mathrm{Tl}$ antigen is probably distinct from several chondroitin sulfate proteoglycans solubilized by PBS extraction of rat brain (Rauch et al., 1991). In addition to requiring denaturing conditions for solubilization, these PBS-soluble proteoglycans have protein core sizes different than that of the T1 antigen (Rauch et al., 1991).

The observation that the $\mathrm{T} 1$ antigen in rat brain is part of a disulfide-stabilized complex with two other proteins is similar to our finding for a chondroitin/keratan sulfate proteoglycan from electric organ of the elasmobranch marine ray (Iwata and Carlson, 1991). This proteoglycan, PG-1000, is associated with basement membranes of the electric organ. PG-1000 is part of a disulfide-stabilized complex with a keratan sulfate proteoglycan and three proteins of $39,000,21,000$, and 18,000 . In the case of the $\mathrm{Tl}$ antigen from rat brain, it is not clear whether the $119 \mathrm{kDa}$ and $53 \mathrm{kDa}$ proteins are separate gene products or the result of proteolytic cleavage of a larger, precursor protein.

We hypothesize that the T1 proteoglycan is a general ECM component of adult brain, like collagen or fibronectin in other organs of the adult (Fawcctt, 1986). This would be one of the few general brain ECM components to be identified and characterized. A proteoglycan like Cat-301 (Zaremba et al., 1989) may also be a component of this matrix. As mentioned previously Cat-301, like the T1 antigen, requires denaturing conditions for solubilization. Perhaps these two proteoglycans are integral structural components of a tightly associated network. However, unlike the T1 antigen, Cat-301 has a restricted neuronal distribution. Thus, Cat-301 might be a neuron-specific component of brain ECM. In addition to these molecules, a number of proteoglycans exist that are extracted from brain tissue by physiological salt alone or by nondenaturing detergents (Herdon and Lander, 1990; Rauch et al., 1991). Some of these proteoglycans may be part of a brain ECM too, but weakly associated with the tightly bound network.

ECM has been implicated in many processes: the specific adhesion of cells (Sanes et al., 1978; Hunter ct al., 1989), molecular filtration (Farquhar, 1981), the creation and maintenance of extracellular space (Comper and Laurent, 1978; Hascall and Hascall, 1981), and as a repository for growth factors (Gonzalez et al., 1990), to name a few. Brain ECM could be involved in all of these processes. Characterization of the components of an ECM increase our understanding of the properties of the intact matrix. This understanding can provide insight into the function of the ECM. If the T1 antigen is a general ECM protein of the hrain, then the $\mathrm{T} 1$ antigen should specifically combine with itself and/or other extracellular macromolecules of the brain to form the matrix. As a test of our hypothesis, we should be able to use the $\mathrm{Tl}$ antigen to find other brain matrix components with which it associates. The characterization of these components should help us understand what kind of matrix is present in brain tissue.

\section{References}

Abbott NJ (1986) The neuronal microenvironment. Trends Neurosci 9:3-6.

Alberts B, Bray D, Lewis J, Raff M, Roberts K, Watson J (1989) Molecular biology of the cell. New York: Garland.

Aquino DA, Margolis RU, Margolis RK (1984) Immunolocalization of a chondroitin sulfate proteoglycan in nervous tissue. 1. Adult brain, retina, and peripheral nerve. J Cell Biol 99:1117-1129.

Antonsson P, Heinegard D, Oldberg A (1989) The keratan sulfate- enriched region of bovine cartilage proteoglycan consists of a consecutively repeated hexapeptide motif. J Biol Chem 264:15170-16173.

Atoji Y, Hori Y, Sugimura M, Suzuki Y (1989) Extracellular matrix of the superior olivary nuclei in the dog. J Neurocytol 18:599-610.

Brown DA, Rose JK (1992) Sorting of GPI-anchored proteins to glycolipid-enriched membrane subdomains during transport to the apical ccll surface. Cell 68:533-544.

Buckley K, Kelly RB (1985) Identification of a transmembrane glycoprotein specific for secretory vesicles of neural and endocrine cells. J Cell Biol 100:1284-1294.

Carlson SS (1989) Synaptic vesicle glycoproteins and proteoglycans. In: Neurobiology of glycoconjugates (Margolis RU, Margolis RK, eds), pp 309-336. New York: Plenum.

Carlson SS, Kelly RB (1983) A highly antigenic proteoglycan-like component of cholinergic synaptic vesicles. J Biol Chem 258:1108211091

Carlson SS, Wight TN (1987) Nerve terminal anchorage protein 1 (TAP-1) is a chondroitin sulfate proteoglycan: biochemical and electron microscopic characterization. J Cell Biol 105:3075-3086.

Carlson SS, Wagner JA, Kelly RB (1978) Purification of synaptic vesicles from clasmobranch electric organ and use of biophysical criteria to demonstrate purity. Biochemistry 17:1188-1199.

Carlson SS, Caroni P, Kelly RB (1986) A nerve terminal anchorage protein from electric organ. J Cell Biol 103:509-520.

Caterson B, Calabro T, Hampton A (1987) Monoclonal antibodies as probes for elucidating proteoglycan structure and function. In: Biology of proteoglycans (Wight TN, Mecham RP, eds), pp 1-26. Orlando, FL: Academic.

Comper WD, Laurent $T$ (1978) Physiological function of connective tisssue polysaccharides. Physiol Rev 58:255-315.

Crossin KL, Hoffman S, Grumet M, Thiery J-P, Edelman GM (1986) Site-restricted expression of cytotactin during development of the chicken embryo. J Cell Biol 102:1917-1930.

Deutsch JW, Raftery MA (1979) Polypeptide composition of acetylcholinc rcceptor purified from teleost and elasmobranch electroplax membranes. Arch Biochem Biophys 197:503-515.

Doege K, Sasaki M, Horigan E, Hassell JR, Yamada Y (1987) Complete primary structure of the rat cartilage proteoglycan core protein deduced from cDNA clones. J Biol Chem 262:17757-17767.

Doege K, Sasaki M, Kimura T, Yamada Y (1991) Complete coding sequence and deduced primary structure of human cartilage large aggregating proteoglycan, Aggrecan. J Biol Chem 266:894-902.

Farquhar MG (1981) The glomerular basement membrane: a selective macromolecular filter. In: Cell biology of extracellular matrix. (Hay ED, ed), pp 335-378. New York: Plenum.

Fawcett DW (1986) Connective tissue proper. In: A Textbook of Histology (Bloom W, Fawcett DW, eds), pp 136-173. Philadephia: Saunders.

Fisher LW, Termine JD, Young MF (1989) Deduced protein sequence of bone small proteoglycan 1 (biglycan) shows homology with proteoglycan II (decorin) and several nonconnective tissue proteins in a variety of species. J Biol Chem 264:4571-4576.

Froehner SC (1986) The role of the postsynaptic cytoskeleton in AChR organization. Trends Neurosci 9:37-41.

Gonzalez A-M, Buscaglia M, Ong M, Baird A (1990) Distribution of basic fibroblast growth factor in the 18-day rat fetus: localization in the basement membranes of diverse tissues. J Cell Biol 110:735-765.

Hascall VC, Hascall GK (1981) Proteoglycans. In: Cell biology of the extracellular matrix (Hay ED, ed), pp 39-63. New York: Plenum.

Hascall VC, Kimura JH (1982) Proteoglycans: isolation and characterization. Methods Enzymol 82:769-800.

Heinegard D, Sommarin Y (1987) Isolation and characterization of proteoglycans. Methods Enzymol 144:319-373.

Helenius A, Simons K (1975) Solubilization of membranes by detergents. Biochim Biophys Acta 415:29-79.

Herndon ME, Lander AD (1990) A diverse set of developmentally regulated proteoglycans is expressed in rat central nervous system. Neuron 4:949-961.

Hockfield S, McKay RD, Hendry SHC, Jones EC (1983) A surface antigen that identifies ocular dominance columns in the visual cortex and laminar features of the lateral geniculate nucleus. Cold Spring Harbor Symp Quant Biol 48:877-889.

Hoffman S, Crossin KL, Edelman GM (1988) Molecular forms, binding functions, and developmental expression patterns of cytotactin and cytotactin-binding proteoglycan, an interactive pair of extracellular matrix molecules. J Cell Biol 106:519-532. 
Hunter DD, Porter BE, Bulock JW, Adams SP, Merlic JP, Sanes JR (1989) Primary sequence of a motor neuron-selective adhesive site in the synaptic basal lamina protein S-laminin. Cell 59:905-913.

Iwata M, Carlson SS (1991) A large chondroitin sulfate basement membrane associated proteoglycan exists as a disulfide-stabilized complex of several proteins. J Biol Chem 266:323-333.

Johnston IG, Paladino T, Gurd JW, Brown IR (1990) Molecular cloning of SC1: a putative brain extracellular matrix glycoprotein showing partial similarity to osteonectin/BM40/SPARC. Neuron 23:165-176.

Kjellen L, Pettersson I, Hook M (1981) Cell-surface heparan sulfate: an intercalated membrane proteoglycan. Proc Natl Acad Sci USA 78: $5371-5375$.

Klinger MM, Margolis RU, Margolis RK (1985) Isolation and characterization of the heparan sulfate proteoglycans of brain. J Biol Chem 260:4082-4090.

Levine JM, Card JP (1987) Light and electron microscopic localization of a cell surface antigen (NG2) in rat cerebellum: association with smooth protoplasmic astrocytes. J Neurosci 7:2711-2720.

Marcantonio EE, Hynes RO (1988) Antibodies to the conserved cytoplasmic domain of the integrin $\beta 1$ subunit react with proteins in vertebrates, invertebrates, and fungi. J Cell Biol 106:1765-1772.

Margolis RU, Margolis RK, Chang LB, Preti C (1975) Glycosaminoglycans of brain during development. Biochemistry 14:85-88.

McBain CJ, Traynelis SF, Dingledine R (1990) Regional variations of extracellular space in the hippocampus. Science 249:674-677.

Neison JW, Hammerton RW (1989) A membrane-cytoskeletal complex containing Na,K-ATPase, ankyrin, and fodrin in Madin-Darby canine kidney (MDCK0) cells: implications for the biogenesis of epithelial cell polarity. J Cell Biol 108:893-902.

Nishiyama A, Dahlin KJ, Prince JT, Johnstone SR, Stallcup WB (1991) The primary structure of $\mathrm{NG} 2$, a novel membrane-spanning proteoglycan. J Cell Biol 114:359-371.

Oike Y, Kimata K, Shinomura T, Nakazawa K, Suzuki S (1980) Structural analysis of chick-embryo cartilage proteoglycan by selective degradation with chondroitin lyases (chondroitinases) and endo- $\beta$-galactosidases (keratinases). Biochem J 191:193-207.

Oohira A, Matsui F, Matsuda M, Yuko T, Kubok Y (1988) Occurrence of three distinct molecular species of chondroitin sulfate proteoglycan in the developing rat brain. J Biol Chem 263:10240-10246.

Paulsson M (1987) Noncollagenous proteins of basement membranes. Collagen Relat Res 7:443-461.

Perides G, I ane WS, Andrews D, Dahl D, Bignami A (1989) Isolation and partial characterization of a glial hyaluronate-binding protein. $\mathbf{J}$ Biol Chem 264:5981-5987.

Phillips WD, Kopta C, Blount P, Gardner PD, Steinbach JH, Merlie JP (1991) ACh receptor-rich membrane domains organized in fibroblasts by recombinant 43-kd protein. Science 251:568-570.

Portera-Cailliau C, Hagg T, Engvall E, Varon S, Manthorpe LM (1990) Merosin, a laminin-like molecule, is associated with neuronal processes in selected regions of the adult rabbit CNS. Soc Neurosci Abstr $16: 314$.
Purves D, Hadlcy RD, Voyvodic JT (1986) Dynamic changes in the dendritic geometry of individual neurons visualized over periods of up to three months in the superior cervical ganglion of living mice. J Neurosci 6:1051-1060.

Purves D, Voyvodic JT, Magrassi L, Yawo H (1987) Nerve terminal remodeling visualized in living mice by repeated examination of the same neuron. Science 238:1122-1126.

Rapraeger A, Bernfield M (1983) Heparan sulfate proteoglycans from mouse mammary epithelial cells. J Biol Chem 258:3632-3636.

Rapraeger A, Bernfield M (1985) Cell surface proteoglycan of mammary epithelial cells. J Biol Chem 260:4103-4109.

Rapraeger $\Lambda$, Jalkanen $M$, Bernfield $M$ (1987) Integral membrane proteoglycans as matrix receptors: role in cytoskeleton and matrix assembly at the epithelial cell surface. In: Biology of proteoglycans (Wight TN, Mecham RP, eds), pp 1-26. Orlando, FL: Academic.

Rauch U, Gao P, Janetzko A, Flaccus A, Hilgenberg L, Tekotte H, Margolis RK, Margolis R (1991) Isolation and characterization of developmentally regulated chondroitin sulfate and chondroitin/ $\mathrm{ker-}$ atan sulfate proteoglycans of brain identified with monoclonal antibodies. J Biol Chem 266:14785-14801

Ripellino JA, Bailo M, Margolis RU, Margolis RK (1988) Light and electron microscopic studies on the localization of hyaluronic acid in the developing rat cerebellum. J Ccll Biol 106:845-855.

Sanes J (1989) Extracellular matrix molecules that influence neural development. Annu Rev Neurosci 12:491-516.

Sanes JR, Marshall LM, McMahan UJ (1978) Reinnervation of muscle fiber basal lamina after removal of myofibers. J Cell Biol 78:176198.

Schonherr E, Jarvelainen HT, Sandell LJ, Wight E (1991) Plateletderived growth factor and transforming growth factor- $\beta 1$ on the synthesis of a large versican-like chondroitin sulfate proteoglycan by arterial smooth muscle cells. J Biol Chem 266:17640-17647.

Sheetz MP (1979) Integral membrane protein interaction with triton cytoskelctons of erythocytes. Biochim Biophys Acta 557:122-134.

Snow AD, Wight TN (1989) Proteoglycans in the pathogenesis of Alzheimer's disease and other amyloidoses. Neurobiol Aging 10:481497.

Timpl R, Rohde H, Robey PG, Rennard S, Foidart J-M, Martin G (1979) Laminin-A glycoprotein from basement membranes. J Biol Chem 254:9933-9937.

Yanagishita M, Midura RJ, Hascall VC (1987) Proteoglycans: isolation and purification from tissues cultures. Methods Fnzymol 138: 279-289.

Zaremda S, Guimaraes A, Kalb RG, Hockfield S (1989) Characterization of an activity-dependent, neuronal surface proteoglycan identified with a monoclonal antibody Cat-301. Neuron 2:1207-1219.

Zimmermann DR, Ruoslahti E (1989) Multiple domains of the large fibroblast proteoglycan, versican. EMBO I 8:2975-2981. 